The Canadian Mineralogist

Vol. 44, pp. 323-340 (2006)

\title{
DIAMOND FROM THE LOS COQUITOS AREA, BOLIVAR STATE, VENEZUELA
}

\author{
FELIX V. KAMINSKY ${ }^{\S}$, OLGA D. ZAKHARCHENKO AND GALINA K. KHACHATRYAN \\ KM Diamond Exploration Ltd., 2446 Shadbolt Lane, West Vancouver, British Columbia V7S 3J1, Canada \\ WILLIAM L. GRIFFIN \\ GEMOC Key Centre, Department of Earth and Planetary Sciences, Macquarie University, Sydney, NSW 2109, \\ and CSIRO Exploration and Mining, North Ryde, NSW 2113, Australia \\ DOMINIC M. DER. CHANNER \\ Guaniamo Mining Company, Centro Gerencial Mohedano, Office 9D, La Castellana, Caracas, Venezuela
}

\begin{abstract}
A set of 77 diamond crystals from the Los Coquitos placer on the Guaniamo River in Bolivar State, Venezuela, has been comprehensively studied and compared to previously studied diamond from the Quebrada Grande kimberlite sills and placer deposits, both located $50 \mathrm{~km}$ to the southeast. The diamond crystals in the Los Coquitos placer are generally similar to those of the Quebrada Grande area, but with significant morphological differences. Diamond from the Los Coquitos placer has a higher total nitrogen content ( $\mathrm{N}_{\text {tot }}=719$ at.ppm versus 614-706 at.ppm in diamond from Quebrada Grande) and a lower level of nitrogen aggregation $\left(\% \mathrm{~N}_{\mathrm{B}}=65\right.$ versus 68 in diamond from Quebrada Grande). Carbon isotope values, $\delta^{13} \mathrm{C}$, of the Los Coquitos diamond vary from +0.4 to $-20.5 \%$, compared with -3.2 to $-28.7 \%$ in the Quebrada Grande diamond. In the Los Coquitos suite, mineral inclusions in diamond are characterized by a lower Ca content in garnet, wider compositional variations in pyroxene $(m g$ in the range 0.683-0.849), and lower Fo component in olivine ( $m g$ in the range 0.926-0.932), compared to inclusions in diamond in the Quebrada Grande suite. Los Coquitos diamond shows greater depletion in LREE compared to Quebrada Grande diamond. Diamond crystals at Los Coquitos were derived, at least in part, from a new, undiscovered kimberlite source in the Guaniamo River basin. These rocks are similar in type to the Quebrada Grande kimberlites, but were sampled from a different section of the subcontinental lithospheric mantle. The existence of two separate populations of diamond, each with its own primary source, suggests that other localities of placer diamond in Venezuela may have their own local sources.
\end{abstract}

Keywords: diamond, infrared spectra, carbon isotopes, Los Coquitos, Guaniamo, Venezuela.

\section{SOMMAIRE}

Nous avons étudié de façon compréhensive une collection de 77 cristaux de diamant provenant du placer de Los Coquitos, sur la rivière Guaniamo, dans l'état de Bolivar, au Venezuela, et nous les avons comparés à la collection de diamant issus des filonscouches de kimberlite de Quebrada Grande et des placers associés, les deux situés à $50 \mathrm{~km}$ au sud-est. Les cristaux de diamant des placers de Los Coquitos sont en général semblables à ceux de Quebrada Grande, mais avec des différences morphologiques importantes. Le diamant des placers de Los Coquitos possède une quantité totale d'azote plus élevée $\left(\mathrm{N}_{\text {tot }}=719\right.$ at.ppm versus 614-706 at.ppm dans le diamant de Quebrada Grande) et une quantité plus faible d'azote en agrégation (\% $\mathrm{N}_{\mathrm{B}}=65$ versus 68 dans le diamant de Quebrada Grande). Les valeurs du rapport isotopique de carbone, $\delta^{13} \mathrm{C}$, du diamant de Los Coquitos varient entre +0.4 et $-20.5 \%$, en comparaison de l'intervalle à Quebrada Grande, entre -3.2 et -28.7\%o. Dans la suite de Los Coquitos, les inclusions minérales du diamant montrent une teneur en Ca plus faible du grenat, des variations compositionnelles plus importantes du pyroxène ( $m g$ sur l'intervalle $0.683-0.849$ ), et de plus faibles teneurs en Fo de l'olivine ( $m g$ sur l'intervalle 0.926-0.932), comparées aux inclusions du diamant de Quebrada Grande. Le diamant de Los Coquitos montre une plus grande déficience en terres rares légères que celui de Quebrada Grande. Les cristaux de diamant de Los Coquitos ont été dérivés, au moins en partie, d'une source kimberlitique méconnue dans le bassin de la rivière Guaniamo. Ces roches ressembleraient à celles de Quebrada Grande, mais seraient dérivées d'un niveau différent du manteau lithosphérique subcontinental. L'existence de deux populations de diamant distinctes, chacune ayant sa propre source primaire, laisse présager d'autres endroits minéralisés au Venezuela qui auraient leurs propres sources.

(Traduit par la Rédaction)

Mots-clés: diamant, spectre infrarouge, isotopes de carbone, Los Coquitos, Guaniamo, Venezuela.

§E-mail address: felixvkaminsky@cs.com 


\section{INTRODUCTION}

Kaminsky et al. (2000, 2004) and Channer et al. (2001) studied diamond from placer deposits of the Quebrada Grande River in the Guaniamo area, Venezuela and demonstrated that, in contrast to previous conclusions, they are not recycled from the Proterozoic Roraima sediments, but are of local origin, derived from 700-800 Ma kimberlite sills located adjacent to the Quebrada Grande (Channer et al. 2001). These findings encouraged an extension of diamond prospection in other areas within Bolivar State, Venezuela, by Guaniamo Mining Company. In the Los Coquitos area, some $50 \mathrm{~km}$ northwest of the Quebrada Grande (Fig. 1), local farmers recovered diamond stones on an artisanal scale from gravels in the lower part of the valley of the

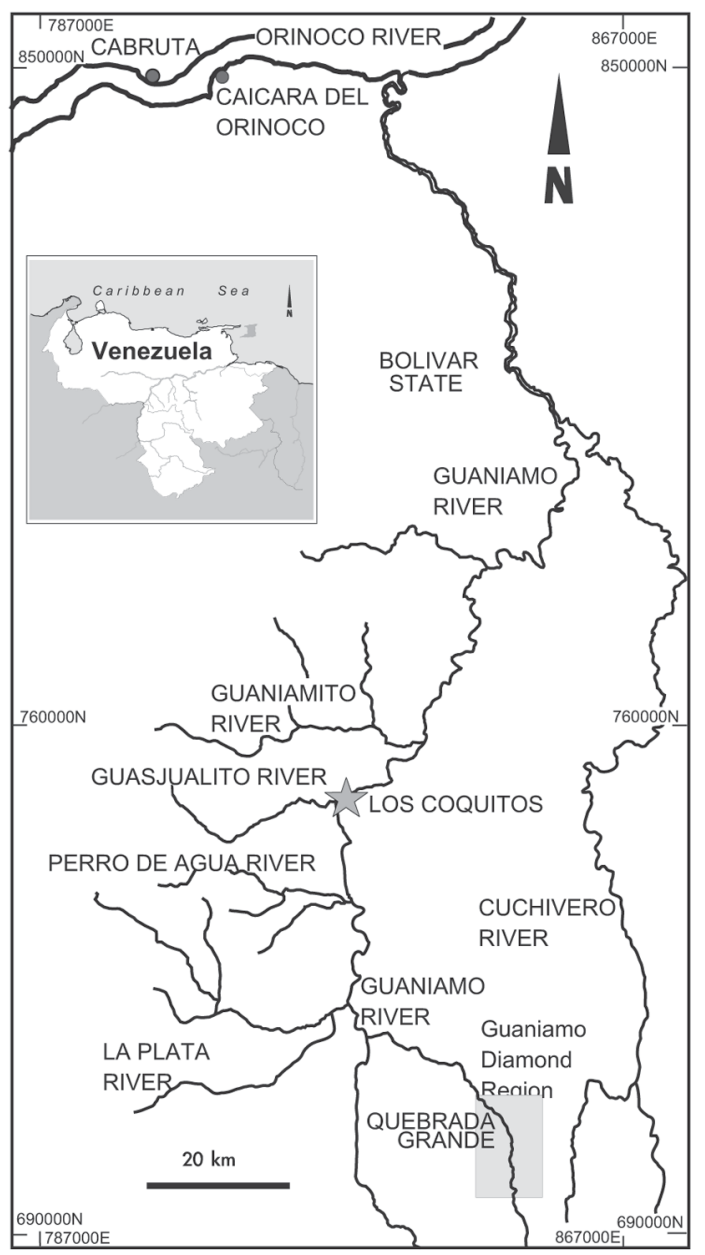

FIG. 1. Map showing the location of the Los Coquitos area, shown as a star.
Los Coquitos River. A parcel of 77 diamond crystals was purchased with the objective of making a detailed comparison with diamond from the Quebrada Grande area, the key question being whether these crystals were derived from the Quebrada Grande suite by downstream transport or from an undiscovered primary source that has different conditions of formation.

\section{SAmple Information AND AnAlytical Methods}

The diamond crystals studied vary in weight from 0.01 to 0.70 ct with an average weight of $30.1 \mathrm{mg}$, which is 4-5 times greater than crystals from the Quebrada Grande sills and placers (6.4 mg and $7.6 \mathrm{mg}$, respectively). Unlike the Quebrada Grande deposits, small crystals of diamond in the range $-1+0.5 \mathrm{~mm}$ are not present in the Los Coquitos sample. This may be partly caused by the rejection of smaller stones by local miners. However, the distribution of diamond numbers and size at Los Coquitos is approximately log-normal, meaning that the diamond parcel is representative of this alluvial deposit. The proportions of $+2 \mathrm{~mm}$ and $-2+1$ $\mathrm{mm}$ diamond crystals are almost equal in number in this placer, whereas in the Quebrada Grande deposits, diamond crystals of size classes $-2+1 \mathrm{~mm}$ dominate in both weight and number (Kaminsky et al. 2000).

Analytical work included characterization of diamond morphology and color, ultraviolet luminescence, infrared spectroscopy, carbon isotopic composition, and the identification and analysis of mineral inclusions. With the exception of a trace-element analysis of mineral inclusions that was carried out at the Geochemical Analysis Unit of Macquarie University, Australia, all analytical work was performed at the Institute of Diamond, Moscow, Russia.

Ultraviolet-induced (UV) luminescence of diamond samples was studied with a "Lusam-R" apparatus, within the wavelength range of 70-100 nm. Photoluminescence (PL) was induced by a SVD-120A mercury-quartz lamp with an UFS-6 filter.

Infrared (IR) spectra were obtained using a Specord M-80 spectrometer (Karl Zeiss, Jena) fitted with a beam condenser. Entire crystals were analyzed in order to obtain the integral spectral characteristics and average nitrogen compositions for each specimen. Spectral resolution was on the order of $6-10 \mathrm{~cm}^{-1}$. Concentrations of $\mathrm{A}$ and $\mathrm{B}$ nitrogen centers were calculated according to the IR absorption coefficients specified by Boyd et al. (1994, 1995). For mixed IaAB diamond type, the Mendelssohn - Milledge (Mendelssohn \& Milledge 1995) method was used. More than one third of the specimens (20 of 52) were submitted for the control analysis. Errors on the concentrations determined were less than $20 \%$. One can find the principles that were used for interpretation of IR analysis of diamond in Kaminsky et al. (2000, 2001b), Kaminsky \& Khachatryan $(2001,2004)$, and Khachatryan \& Kaminsky (2003). 
Isotope analyses were performed by K. Maltsev (GEOHI, Russia) using samples from 2 to $15 \mathrm{mg}$ in weight with the VARIAN-MAT-230 mass spectrometer; this was done with an accuracy of $<0.1 \%$ PDB $\left({ }^{13} \mathrm{C} /{ }^{12} \mathrm{C} \mathrm{PDB}=0.0112372\right)$. After initial preparation, crystals of diamond were oxidized to $\mathrm{CO}_{2}$ in sealed tubes using an $\mathrm{O}_{2}$ flux (circular system, $900^{\circ} \mathrm{C}$ ). The isotopic composition is given in the delta notation (parts per thousand) as the deviation from the PDB standard.

Inclusions were extracted from their hosts by cracking the diamond; analysis of major and minor elements was then carried out using a Cameca Camebax electron microprobe with a $15 \mathrm{kV}$ acceleration voltage and $15 \mathrm{nA}$ beam current.

Trace-element analyses of selected inclusions of mineral phases were carried out by laser-ablation microprobe ICP-MS, using techniques similar to those described by Kaminsky et al. (2000, 2001a).

\section{MORPHOLOGY OF THE DiAMOND}

Diamond crystals from the Los Coquitos placer include dodecahedroids $(36.3 \%)$, octahedra $(24.7 \%)$, octahedral-dodecahedral (O-D) combination crystals $(28.6 \%)$, and twins and aggregates. In addition, there are diamond crystals of uncertain habit (10.4\%), which are typically bounded on all sides by spallation surfaces. At both Los Coquitos and the Quebrada Grande (Table 1), dodecahedroids are predominant, but at Los Coquitos, their proportion is lower. Los Coquitos has a significantly higher proportion of octahedral and combination types. In general, within the Los Coquitos placer, the smaller the diamond size-fraction, the lower the proportion of octahedra and the higher the proportion of dodecahedroids and diamond crystals of uncertain habit.

Crystal faces bear various accessory and microrelief surface-features of different sizes and shapes. These are well described in earlier studies from other regions (e.g., Tolansky 1955, Kukharenko 1955, Bartoshinsky 1962, Orlov 1984). The nature of these surface features is controlled by the crystallization process, natural oxidation-related dissolution (resorption), and plastic deformation of the diamond. Features observed in the Los Coquitos diamond crystals are described below,

TABLE 1. MORPHOLOGICAL TYPES OF DIAMOND IN VENEZUELA*

\begin{tabular}{|c|c|c|c|c|c|}
\hline Location & $\begin{array}{l}\text { No. of } \\
\text { stones }\end{array}$ & $\begin{array}{l}\text { Octa- } \\
\text { hedra }\end{array}$ & $\begin{array}{l}\text { Dodeca- } \\
\text { hedroids }\end{array}$ & $\begin{array}{c}\text { Combination } \\
\text { type }\end{array}$ & Un- \\
\hline Los Coquitos & 77 & 24.7 & 36.3 & 28.6 & 10.4 \\
\hline Quebrada Grande placer & 794 & 5.1 & 44.5 & 10.1 & 40.3 \\
\hline Quebrada Grande sills & 1311 & 2.1 & 49.7 & 16.3 & 31.9 \\
\hline
\end{tabular}

$* \%$ of stones. and compared with those observed in Quebrada Grande diamond by Kaminsky et al. (2000).

\section{Octahedral crystals}

Octahedral diamond crystals are represented by octahedra with ditrigonal faces that occasionally show polycentric apex-growth. Octahedra with lamellarstepped trigonal faces or with polycentric face-growth were not observed, in contrast to the Quebrada Grande suite. Diamond surfaces bear sheaf-like, sheaf-hackly, coarse columnar and groove-like features (Fig. 2A).

\section{Crystals of rhombicododecahedral habit}

Diamond crystals of rhombicododecahedral habit are all rounded dodecahedroids. Kaminsky et al. (2000) divided the Quebrada Grande dodecahedral diamond crystals into six groups, depending on the type of surface feature. Only three of these groups are present in Los Coquitos: dodecahedroids with sheaf-like concentric striations (Fig. 2B), hackly (with hillocks, after Robinson et al. 1989), and droplet-like. Smooth, shagreen and blocky features were not observed in Los Coquitos dodecahedroids. Approximately 50\% of Los Coquitos dodecahedroids are non-distorted, equidimensional crystals and $50 \%$ are flattened along the (111) axis. Only a few complexly distorted dodecahedroids were observed. The Los Coquitos placer shows a restricted spectrum of dodecahedroid varieties compared to the Quebrada Grande deposits. It is noteworthy that rounded dodecahedroids with latent laminations are rare and represent less than $3 \%$ of the total number of diamond crystals studied.

\section{Crystals showing combinations}

Combination-type diamond crystals (octahedron + dodecahedroid) are almost evenly developed (111) with (110) faces. Their (111) faces are ditrigonal or irregularly shaped. They show step-plate development, and etch triangles are common. The (110) curved surfaces show three microrelief forms: sheaf-like striations (Fig. 2C), hackly features, and hackly-to-shagreen features. Sheaflike striations and hackly features are much more abundant at Los Coquitos (21\% and 6.5\%) relative to the Quebrada Grande sills (9\% and 2\%) and placers (6\% and $1.3 \%)$. In addition, a few combination crystals with hackly-to-shagreen and droplet-like surface features were found only in diamond from Los Coquitos.

\section{Crystals of uncertain habit}

Diamond crystals of uncertain habit are typically bounded on all sides by protomagmatic or mechanically induced spallation surfaces. In the majority of cases, these diamond crystals show numerous joints. In general, however, diamond from Los Coquitos has 

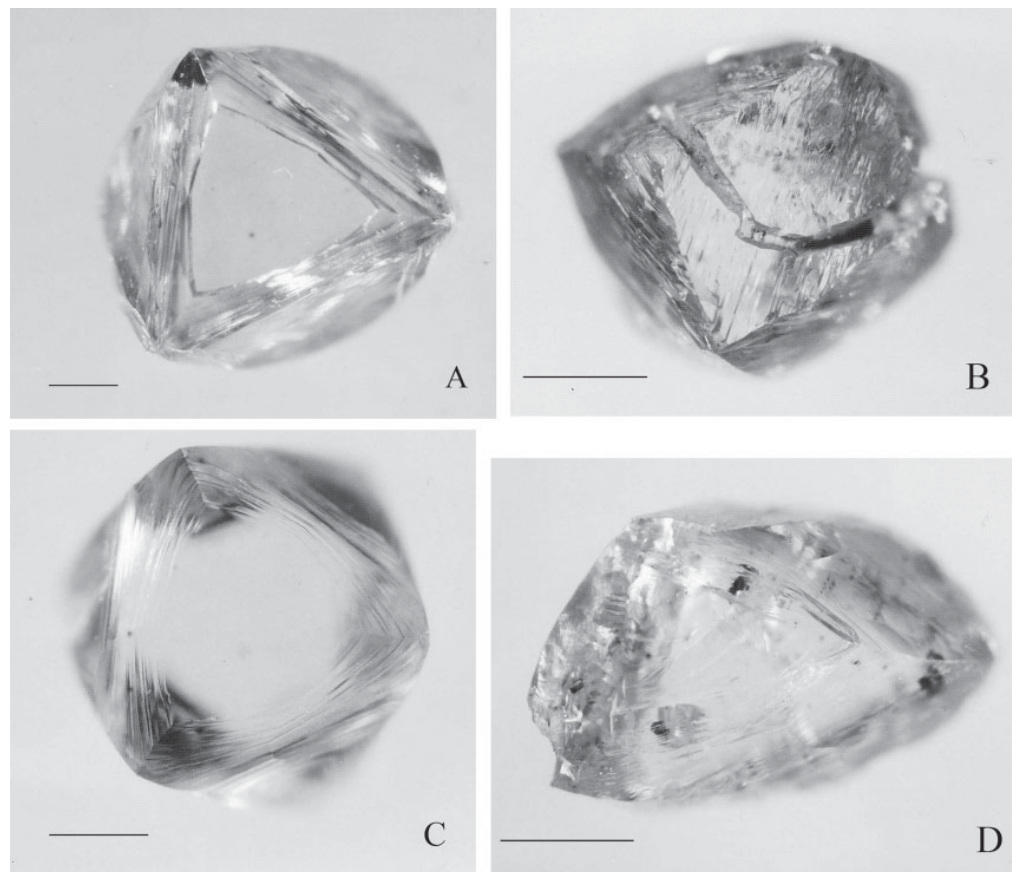

FIG. 2. Morphological features of diamond crystals from Los Coquitos. A. Octahedron with ditrigonal faces. B. Concentric striation with an etch channel on the surface of a rhombicododecahedral crystal. C. Sheaf-like striations on curved surfaces of a combination-type crystal. D. Spinel-type twin of a dodecahedroid with garnet and sulfide inclusions. Scale bar is $0.5 \mathrm{~mm}$.

a lower proportion of multiply jointed stones $(48 \%)$ than the Quebrada Grande deposits (74 to $77 \%$ ). The proportion of diamond crystals of uncertain habit in the Los Coquitos placer increases sharply as diamond size decreases.

\section{Twins and aggregates}

The overall abundance of twins and aggregates in the Los Coquitos placer (26\%) is slightly higher than in the Quebrada Grande sills and placers $(22.2 \%$ and $18.6 \%$, respectively). The relative proportions of dodecahedroid twins and aggregates are similar, whereas the proportions of twins and aggregates of octahedral and combination-type crystals are significantly higher in the Los Coquitos placer (41.6\%) than in the Quebrada Grande deposits (3.0\% in sills, $5.0 \%$ in placers). The dominant types of twins observed are simple spinel-type twins with ditrigonal shapes in the case of the octahedra, and spherical-trigonal shapes in the case of dodecahedroids (Fig. 2D). Complex twins occur more rarely. Aggregates typically consist of two or three crystals of approximately equal size. In some cases, aggregates are represented by ingrowths of small crystals in larger ones. Polycrystalline aggregates are rare.

\section{Epigenetic alteration}

Epigenetic alteration of diamond crystals includes surface features that reflect processes such as natural oxidation and dissolution, plastic deformation and mechanical abrasion marks caused by transportation of crystals in alluvium.

Oxidation-dissolution of diamond results in the formation of various etch features, vugs and channels. Octahedral crystals most commonly show etch patterns in the form of strongly parallel trigonal pits. These features are truncated by more rarely acute-apex negative pyramids with smooth or textured walls. In some cases, they occur as isolated pits (Fig. 3A), or in groups, and may form a continuous pattern on (111) faces (Fig. 3B).

Etch channels are typically developed in zones of weakness, such as, joints, cleavage lines and glide planes. The channels vary in shape (straight, curved), width (from thin to wide, up to vuggy shapes), length and the degree of development.

Plastic deformation shows up on crystal surfaces as striations or relief banded patterns. In some cases, plastic deformation bands are complicated by etch triangles (Fig. 3C). About $62 \%$ of the diamond crystals studied 

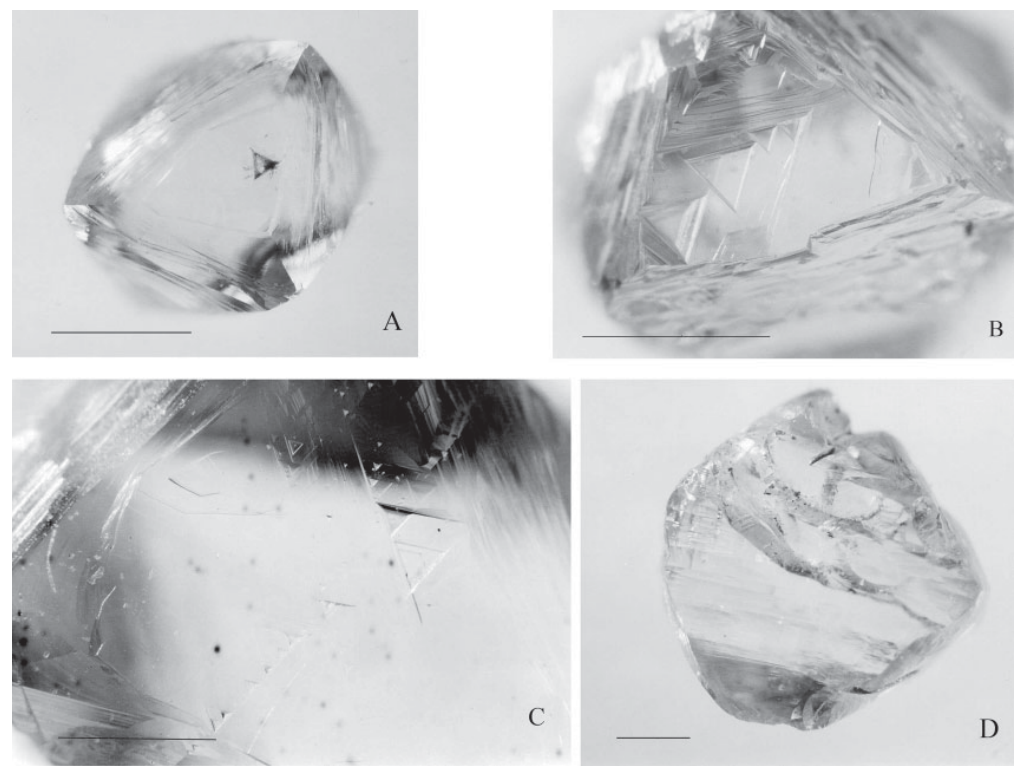

FIG. 3. Postgenetic alteration in diamond crystals from Los Coquitos. A. Isolated dissolution-pits. B. Numerous triangular pits. C. Fine bands of plastic deformation with trigonal pits and coarse bands. D. Well-developed combined spallation-induced surface. Scale bar is $0.5 \mathrm{~mm}$.

from the Los Coquitos placer show plastic deformation bands, which is lower than in the Quebrada Grande sills $(69 \%)$ and Quebrada Grande placers $(80 \%)$.

None of the diamond crystals studied from the Los Coquitos placer exhibits any marks of intense mechanical abrasion, such as crescentiform and annular joints, diamond-shaped pattern or mechanical abrasion of crystal faces, and blunted and rounded edges and apices, which would point to the effects of coastal-marine and long-distance alluvial transport (Kaminsky et al. 2001b, Figs. 13-14). Only a few crystals bear single surficial fissures, most of which are oriented perpendicular to crystal edges. Most commonly, the diamond crystals have very smooth, sharp-edged mechanically produced spallation surfaces. These spallation marks vary from small pits on edges of intact crystals to large mechanically formed spallation areas (Fig. 3D). Such spallation surfaces bear no pronounced abrasion marks, except for insignificant crumbling of thin and sharp crystal edges.

\section{DiAMOND COLOR AND TRANSPARENCY}

Most of the Los Coquitos diamond crystals (50.6\%) are colorless, as in the Quebrada Grande deposits $(49.0 \%)$. With decreasing size of the crystals, the proportion of colorless diamond in the Los Coquitos placer decreases, whereas the proportion of all colored varieties increases.

The colored stones from Los Coquitos are smoky brown $(9.1 \%)$, grey $(16.9 \%)$, green $(22.1 \%)$ and yellow $(1.3 \%)$. The smoky brown color is the result of plastic deformation of the diamond crystals, the grey coloration is caused by the presence of numerous black graphite-like inclusions, and the green coloration is due to pigmentation spots on diamond surfaces. Compared with the Quebrada Grande deposits, material from the Los Coquitos placer has a lower proportion of smokybrown and grey crystals and is characterized by the presence of yellow crystals, which are absent in the Quebrada Grande deposits. Some crystals show a rusty coloration resulting from the presence of iron hydroxides in surficial pits. The rusty coloration was not taken into consideration when classifying diamond by color.

Of the Los Coquitos diamond crystals, $84.4 \%$ bear green pigmentation spots, which is significantly higher than in the Quebrada Grande placers (69.5\%), where brown pigmentation spots have also been observed (Kaminsky et al. 2000).

The combined proportion of semitransparent and non-transparent diamond crystals in the Los Coquitos placer $(71 \%)$ is lower than in the Quebrada Grande sills $(84 \%)$ and placers $(92 \%)$. With decreasing size of the diamond, the proportion of transparent crystals in 
the Los Coquitos placer decreases, whereas the proportion of semitransparent and non-transparent diamond increases.

\section{Photoluminescence of The Diamond}

The majority ( $80 \%$ ) of the diamond crystals from the Los Coquitos placer show blue photoluminescence (PL). The proportion of diamond showing no visible luminescence is $11.7 \%$, and only a few crystals show yellow, green or uncertain luminescence.

The diamond crystals studied were subdivided into two categories depending on whether the PL color is spatially homogeneous or heterogeneous. Diamond crystals with homogeneous blue or yellow PL were, in turn, subdivided into three subgroups of crystals with strong, medium, and weak luminescence. PL-inhomogeneous crystals were subdivided into zoned and block-type crystals.

All PL-inhomogeneous diamond crystals from the Los Coquitos placer are zoned crystals, with yellow

TABLE 2. CHARACTERISTICS OF NITROGEN AND HYDROGEN CENTERS IN DIAMOND FROM LOS COQUTTOS

\begin{tabular}{|c|c|c|c|c|c|c|}
\hline \multirow{2}{*}{$\begin{array}{l}\text { Sample } \\
\text { No. }\end{array}$} & \multicolumn{3}{|c|}{ Nitrogen, at.ppm } & \multirow[t]{2}{*}{$\% \mathrm{~N}_{\mathrm{B}}$} & \multirow{2}{*}{$\begin{array}{l}\text { Platelets } \\
\mathrm{cm}^{\prime}\end{array}$} & \multirow{2}{*}{$\begin{array}{c}\text { Hydrogen } \\
\mathrm{cm}^{i}\end{array}$} \\
\hline & $\mathrm{N}_{\mathrm{A}}$ & $\mathbf{N}_{8}$ & $\mathrm{~N}_{\text {tat }}$ & & & \\
\hline 1 & 69 & 84 & 153 & 54 & 1.1 & 0 \\
\hline 2 & 129 & 129 & 258 & 50 & 3.4 & 0 \\
\hline 4 & 335 & 297 & 632 & 46 & 7.4 & 0 \\
\hline 5 & 59 & 161 & 220 & 73 & 2.6 & 0 \\
\hline 6 & 312 & 618 & 930 & 66 & 15.1 & 0.9 \\
\hline 10 & 175 & 384 & 559 & 68 & 13.1 & 0.3 \\
\hline 14 & 171 & 425 & 596 & 71 & 14.3 & 0 \\
\hline 16 & 207 & 870 & 1077 & 80 & 23.4 & 0 \\
\hline 21 & 256 & 489 & 745 & 65 & 14.3 & 1.8 \\
\hline 22 & 257 & 193 & 450 & 42 & 5.1 & 0.5 \\
\hline 24 & 207 & 632 & 839 & 75 & 19.4 & 0.7 \\
\hline 25 & 152 & 261 & 413 & 63 & 8.9 & 0.5 \\
\hline 26 & 235 & 470 & 705 & 66 & 13.7 & 0.8 \\
\hline 27 & 134 & 718 & 852 & 84 & 12 & 0.3 \\
\hline 28 & 419 & 280 & 699 & 40 & 4.3 & 0.1 \\
\hline 30 & 155 & 787 & 942 & 83 & 20.9 & 0.5 \\
\hline 31 & 14 & 50 & 64 & 78 & 1.1 & 0.3 \\
\hline 32 & 205 & n.d. & 205 & n.d. & 17.7 & 0.3 \\
\hline 33 & 103 & 828 & 931 & 88 & 16 & 1.2 \\
\hline 34 & 116 & 295 & 411 & 71 & 7.1 & 0.3 \\
\hline 35 & 322 & 467 & 789 & 59 & 12.9 & 0.5 \\
\hline 36 & 186 & n.d. & 186 & n.d. & 18.6 & 0.3 \\
\hline 38 & 471 & 332 & 803 & 41 & 15.4 & 0.3 \\
\hline 45 & 189 & 525 & 714 & 73 & 13.7 & 1 \\
\hline 46 & 437 & 1032 & 1469 & 70 & 19.7 & 1.4 \\
\hline 48 & 253 & 691 & 944 & 73 & 12.3 & 7.6 \\
\hline 49 & 178 & 796 & 974 & 81 & 20.3 & 2.7 \\
\hline 50 & 130 & 134 & 264 & 50 & 4 & 0.4 \\
\hline 52 & 122 & 214 & 336 & 63 & 1.7 & 0.6 \\
\hline 53 & 163 & 554 & 71.7 & 77 & 16.9 & 0.5 \\
\hline 54 & 193 & 791 & 984 & 80 & 22 & 2.3 \\
\hline 55 & 255 & 410 & 665 & 61 & 7.7 & 1.1 \\
\hline 56 & 85 & 215 & 300 & 71 & 2.9 & 0 \\
\hline 59 & 570 & 395 & 965 & 40 & 20.3 & 0 \\
\hline 63 & 458 & 627 & 1085 & 57 & 16.6 & 0 \\
\hline 64 & 202 & 364 & 566 & 64 & 11.4 & 0.9 \\
\hline 66 & 263 & 328 & 591 & 55 & 8.3 & 0 \\
\hline 67 & 251 & 338 & 589 & 57 & 6.6 & 0.5 \\
\hline 70 & 229 & 647 & 876 & 73 & 18.6 & 0.6 \\
\hline 71 & 282 & 565 & 847 & 66 & 14.3 & 0.4 \\
\hline
\end{tabular}

PL emitted from cores and blue luminescence from grain margins.

Comparison of the luminescent properties of diamond crystals from the Los Coquitos placer and the Quebrada Grande sills and placer reveals that the Los Coquitos diamond crystals have a much higher proportion of blue (especially strong) luminescence, and lower proportions of yellow, green, uncertain and inhomogeneous luminescence than the Quebrada Grande placers. The proportions of diamond showing no visible luminescence are almost the same in all three deposits. The Los Coquitos placer is characterized by the absence of diamond crystals with pink PL and block-type PLinhomogeneous crystals. With decreasing size of the crystals, the proportion with blue (especially strong) luminescence decreases, and the proportion with green, yellow and uncertain luminescence increases.

\section{INFRARED SPECTROSCOPY AND NITROGEN IMPURITIES}

Fifty-two crystals of diamond were analyzed for A, $\mathrm{B}$ and $\mathrm{P}$ nitrogen centers and hydrogen impurities. The models and properties of these impurity centers are described in Kaminsky et al. (2000) and Kaminsky \& Khachatryan (2001). The crystals studied can be subdivided into three populations based on their IR spectral features: 1) crystals with a predominance of B nitrogenimpurity centers over A centers, 2) crystals with approximately equal proportions of A and B centers, 3 ) crystals with low concentrations (compared to that of the first two populations) of all nitrogen-impurity centers, with unequal proportions of $\mathrm{A}$ and $\mathrm{B}$ centers.

Hydrogen as a structurally bound impurity was detected in moderate amounts in almost all crystals studied (Table 2).

In general, the IR spectra of diamond from the Los Coquitos placer are similar to those of diamond from the Quebrada Grande sills and placers (Kaminsky et al. 2000). Both sets of diamond belong to Group 2 (Kaminsky \& Khachatryan 2001), moderate-nitrogen diamond (which includes most known populations of diamond), with an average nitrogen aggregation, B, of $60-70 \%$ (Fig. 4). The similarity between diamond crystals from the Los Coquitos and Quebrada Grande placers is confirmed by comparison of average values of nitrogen centers, hydrogen impurity and platelets in Figures 5 and 6. Average hydrogen and platelet values (both in relative proportions, according to Kaminsky \& Khachatryan 2001) in the Los Coquitos diamond crystals are comparable with those from Quebrada Grande. At the same time, diamond from the Los Coquitos placer has a slightly higher total nitrogen content $\left(\mathrm{N}_{\text {tot }}=719\right.$ at.ppm versus 614 at.ppm and 706 at.ppm in diamond from Quebrada Grande sills and placers, respectively), and a lower level of nitrogen aggregation $\left(\mathrm{N}_{\mathrm{B}}=65 \%\right.$, versus $68 \%$ in diamond from Quebrada Grande, both sills and placers). 


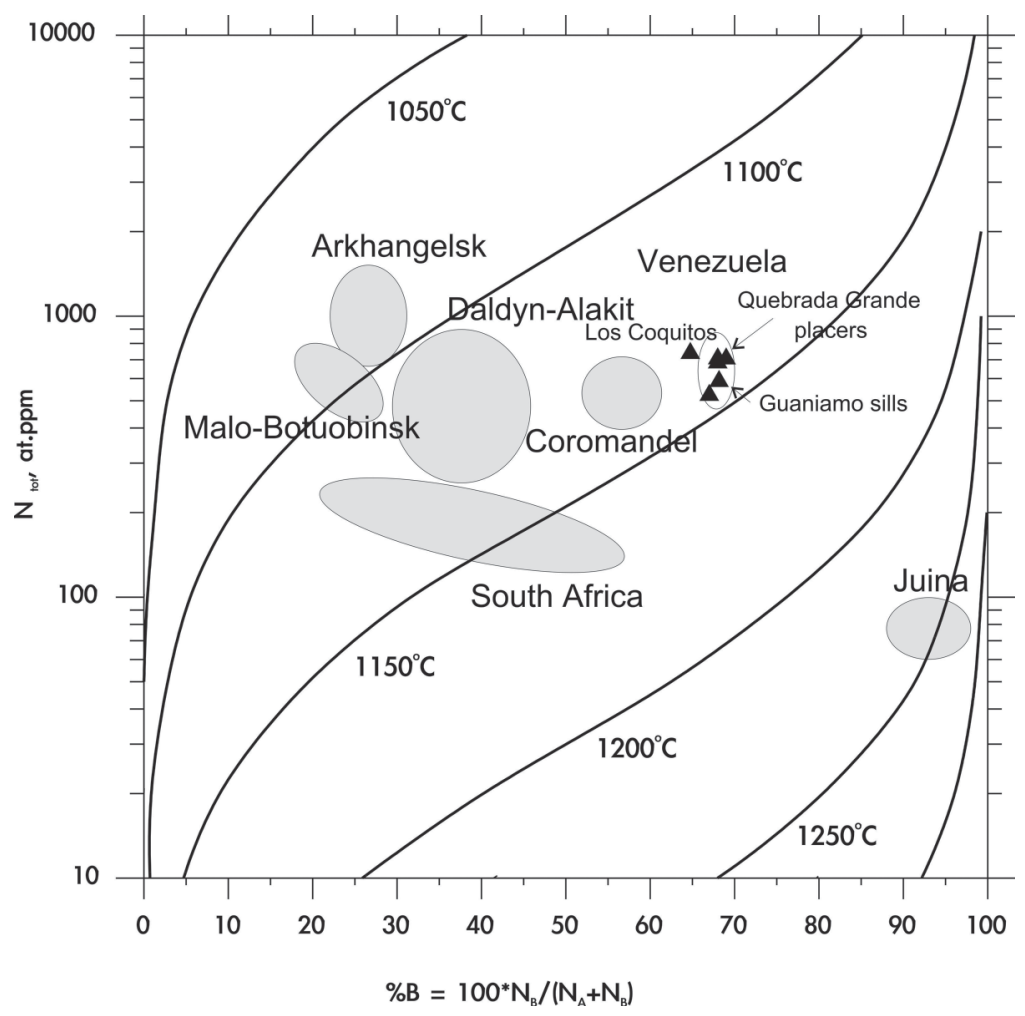

FIG. 4. Taylor-Milledge diagram (Taylor \& Milledge 1995) for diamond crystals from different areas worldwide. Isotherm curves are for $3 \mathrm{Ga}$.

These differences are visible in the distribution curves for each impurity center (Fig. 7). The platelet distribution in crystals from both Los Coquitos and the Quebrada Grande has a bimodal character (Fig. 7-P). However, in the Los Coquitos placer, crystals with relatively higher concentrations of platelets (mode at 15) are predominant; in Quebrada Grande crystals, the platelet mode is at 11 . On the other hand, the hydrogen impurity value in the Los Coquitos crystals $\left(\ln \alpha_{3107}=-1.1\right)$ is lower than in diamond from Quebrada Grande placers and sills $(0.15$ and -0.2 , respectively) (Fig. $7-\mathrm{H})$.

As a result, the relative abundance of A nitrogen centers with respects to $\mathrm{B}$ and $\mathrm{P}$ centers is somewhat higher in diamond crystals from the Los Coquitos

FIG. 5. Distribution of hydrogen $(\mathrm{H})$ and proportion of aggregated nitrogen $\left[\% \mathrm{~N}_{\mathrm{B}}=100 * \mathrm{~N}_{\mathrm{B}} /\left(\mathrm{N}_{\mathrm{A}}+\mathrm{N}_{\mathrm{B}}\right)\right]$ in diamond from various regions. $\mathrm{H}$ is the average hydrogen content in diamond in arbitrary units as a function of the value of the absorption coefficient measured at $3107 \mathrm{~cm}^{-1}$. Diagram after Kaminsky \& Khachatryan (2001).

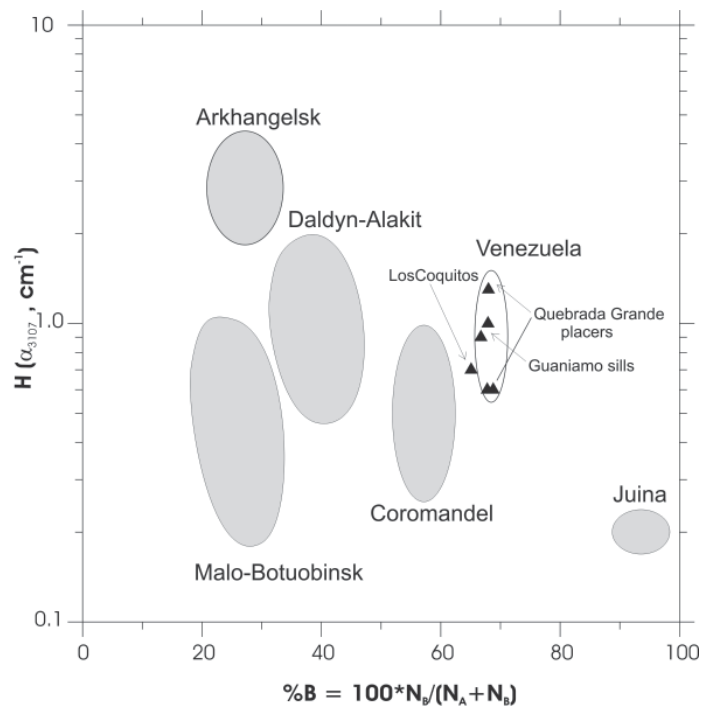




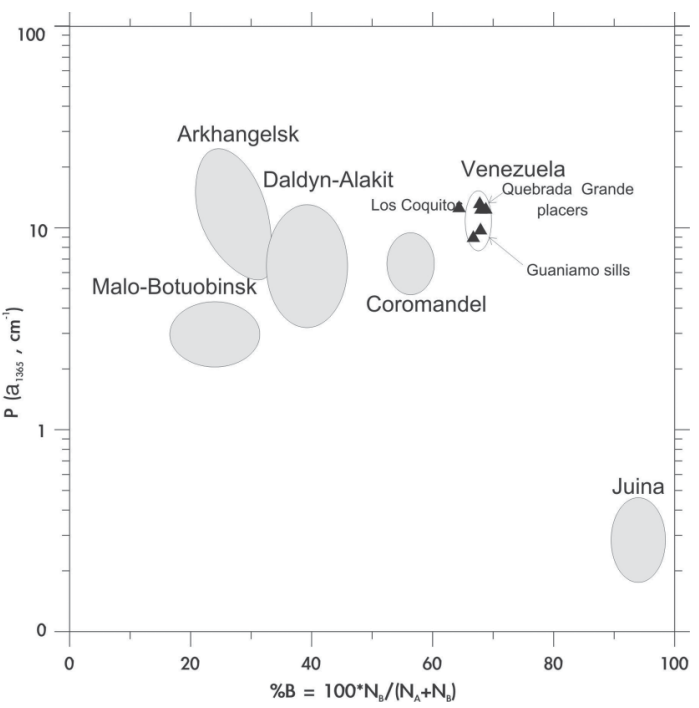

FIG. 6. Distribution of "platelets" and proportion of aggregated nitrogen $\left(\% \mathrm{~N}_{\mathrm{B}}\right)$ in diamond from various regions. $\mathrm{P}$ is an average "platelet" content in diamond, in arbitrary units, as a function of the value of the absorption coefficient measured at $1365 \mathrm{~cm}^{-1}$. Diagram after Kaminsky \& Khachatryan (2001). placer. This difference may point to dissimilar thermal and kinetic parameters during the formation of the two groups of diamond.

\section{CARBON ISOTOPIC COMPOSITION OF DiAMOND CRYSTALS}

The isotopic composition of carbon in diamond reflects its mantle source, and therefore may vary from deposit to deposit. Thus, it is a useful diagnostic characteristic in prospection and evaluation studies. Numerous results of carbon-isotope analyses are available for diamond from many diamondiferous provinces and regions worldwide; $\delta^{13} \mathrm{C}$ values vary from $-34.4 \%$ to $+2.7 \%$. More than $80 \%$ of diamond crystals from kimberlites and lamproites show a limited range of $\delta^{13} \mathrm{C}$ variation, from $-2 \%$ o to $-9 \%$, with a peak around $-5 \%$, interpreted as the average carbon isotopic composition of the mantle.

Twenty-nine diamond crystals (fifteen dodecahedroids, eight $\mathrm{O}-\mathrm{D}$ combination-type crystals and six octahedra) from the Los Coquitos placer were analyzed for their carbon isotope composition (Table 3). Most of them have mineral inclusions, which allowed the determination of paragenetic type for each diamond crystal.
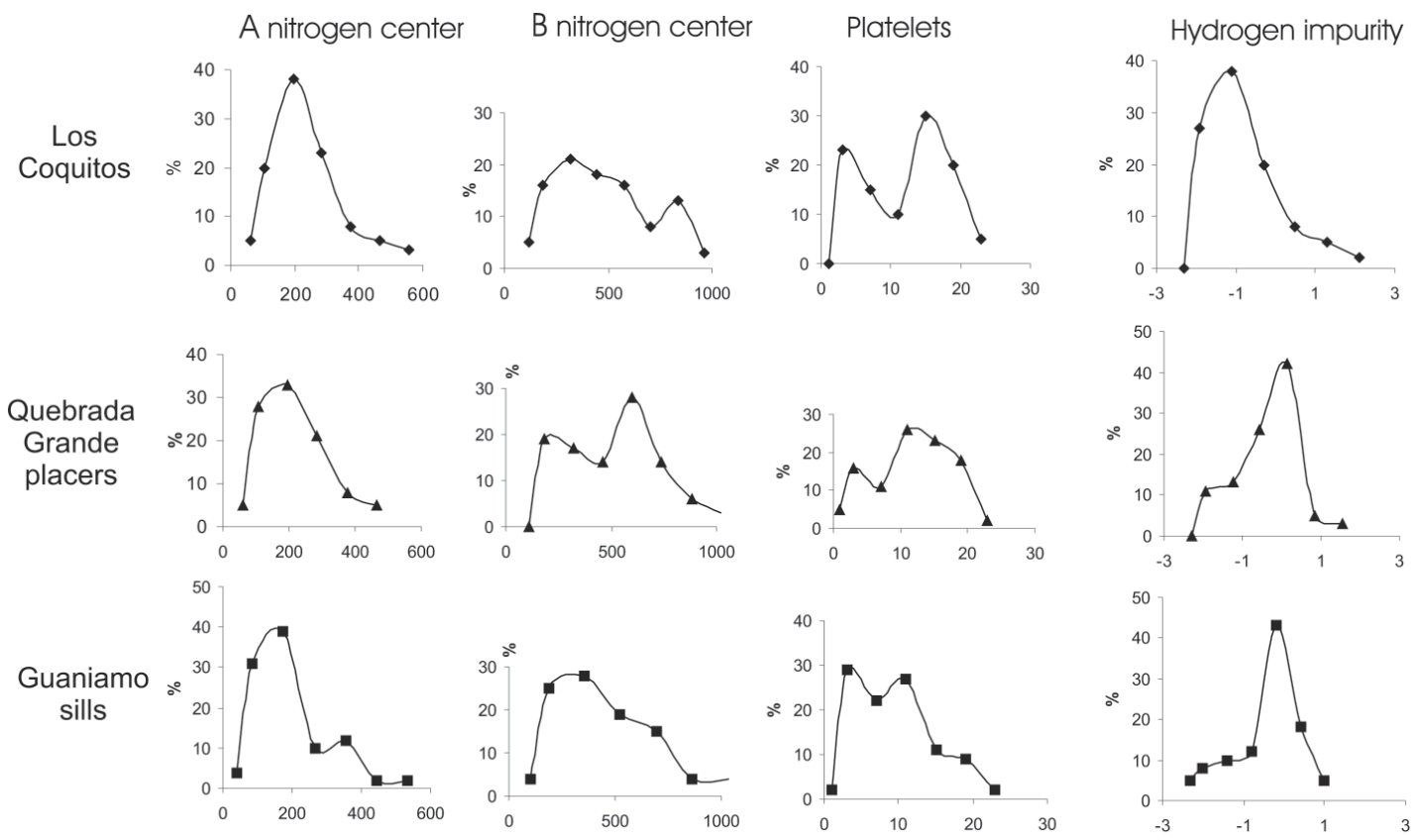

FIG. 7. Distributions of diamond crystals from the Los Coquitos placer $(n=40)$, the Quebrada Grande placers $(n=40)$ and Quebrada Grande kimberlite sills $(n=51)$ in terms of the concentration of A, B, platelets $(\mathrm{P})$ and hydrogen $(\mathrm{H})$ nitrogenimpurity centers. A and B in at.ppm, P is in $\mathrm{cm}^{-1}, \mathrm{H}$ is in $\ln \alpha_{3107}$. Diagram after Kaminsky \& Khachatryan (2001). 
The $\delta^{13} \mathrm{C}$ values of the Los Coquitos diamond crystals vary from +0.4 to $-20 \%$, compared to $-3.2 \%$ to $-28.7 \%$ for the Quebrada Grande deposits. As in the Quebrada Grande sills and placers (Kaminsky et al. 2000), isotopically light diamond with $\delta^{13} \mathrm{C}<-10 \%$ o predominates $(58 \%$ and $92 \%$ in the Los Coquitos placer and Quebrada Grande deposits, respectively). Such predominance is only observed in a few diamond deposits, e.g., the Argyle pipe in Australia (Sobolev et al. 1989), the Sloan pipe in the Wyoming-Colorado area, USA (Otter et al. 1989) and the Ebelyakh placer deposit in northern Siberia (Galimov et al. 1978). It is worth noting that one of the diamond crystals studied has a positive $\delta^{13} \mathrm{C}$ value $(+0.4 \%)$.

With histograms in Figure 8, we compare the distribution of carbon isotope compositions in diamond crystals from the Los Coquitos placer and the Quebrada Grande placers and sills. At Los Coquitos, there is a higher proportion of isotopically heavy crystals than at the Quebrada Grande deposits: 12 of the 29 diamond crystals $(41.4 \%)$ from Los Coquitos are "heavier" than $-10 \%$ PDB, whereas only $11.8 \%$ of crystals from Quebrada Grande have $\delta^{13} \mathrm{C}>-10 \%$ PDB. This is a significant (four times) difference between crystals from the two regions.

\section{Mineral InClusions in Diamond}

The majority of inclusions in the Los Coquitos diamond crystals are grey or black, and are present in $53 \%$ of the crystals from Los Coquitos. They occur as thin plates, discs or rosette-like inclusions. By analogy with inclusions from other regions, the first two types are usually graphite; the rosette-like inclusions are typically sulfides. In cases where grey and black inclusions are numerous, the crystals take on a grey coloration. However, from a genetic standpoint, the most important information was derived from silicate mineral inclusions formed under mantle conditions (Fig. 9).

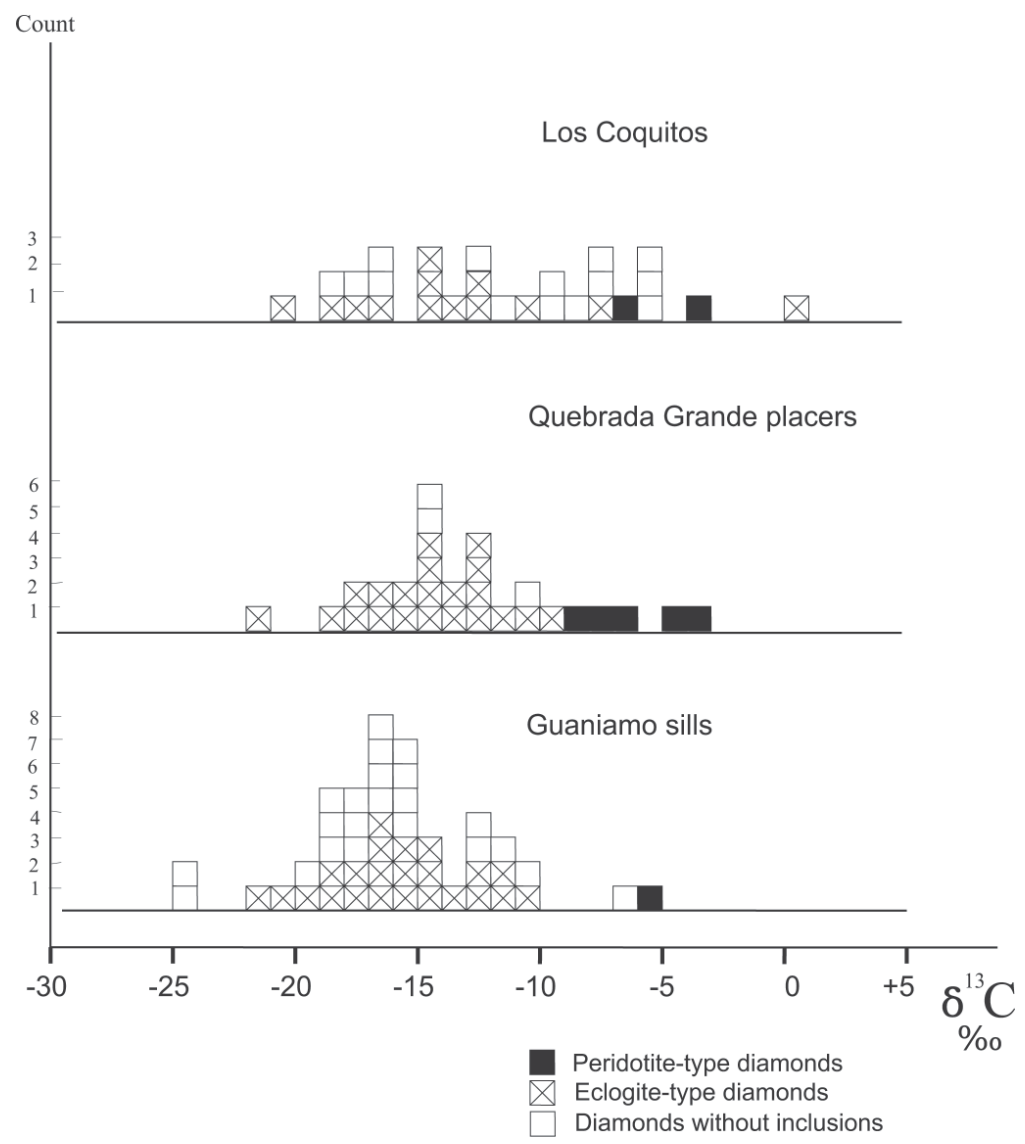

FIG. 8. $\quad \delta^{13} \mathrm{C}$ composition of diamond crystals from the Los Coquitos and the Quebrada Grande placers and sills. 
Syngenetic inclusions of mantle minerals in diamond crystals worldwide fall into three main paragenetic suites: the peridotitic suite (U or P type), the eclogitic suite (E type) and the superdeep suite (SD type). This last type represents diamond crystals derived from the lower mantle and transition zone. These three paragenetic suites correspond to distinct environments of diamond growth (Meyer 1982, Harte \& Harris 1994).

The absolute and relative abundance of diamond crystals containing ultramafic- and eclogitic-suite mineral inclusions is variable, although most deposits are dominated by diamond crystals containing ultramafic-suite inclusions. In some deposits, the proportion of diamond crystals containing eclogitic-suite inclusions is relatively high, e.g., the Orapa pipe (Gurney \& Harris 1982), the Premier pipe (Gurney et al. 1985), the Argyle pipe (Sobolev et al. 1989), some pipes in the Arkhangelsk region (Zakharchenko et al. 1991), and several pipes in the Slave craton (Davies et al. 2004).

The diamond crystals in the Los Coquitos district studied herein contain mineral inclusions of the eclogitic and ultramafic suites. A characteristic feature of Los Coquitos shared with the Quebrada Grande placers and sills (Kaminsky et al. 2000) is the marked predominance of crystals with mineral inclusions of the eclogitic suite.

Twenty-seven mineral inclusions were extracted from nineteen Los Coquitos diamond crystals and

TABLE 3. CARBON ISOTOPIC COMPOSITION OF DIAMOND FROM LOS COQUITOS

\begin{tabular}{|c|c|c|c|}
\hline $\begin{array}{l}\text { Sample } \\
\text { No. }\end{array}$ & Morphology & $\begin{array}{c}\text { Type of } \\
\text { paragenesis* }\end{array}$ & $\begin{array}{c}\delta^{13} \mathrm{C} \\
\% \text { PDB }\end{array}$ \\
\hline 11 & Dodecahedroid & U & -3.3 \\
\hline 15 & $O+D$ combination & $\mathrm{E}$ & -13.4 \\
\hline 21 & Octahedron & $\mathrm{E}$ & -16.1 \\
\hline 23 & Octahedron & $\mathrm{U}$ & -6.1 \\
\hline 25 & Dodecahedroid & $\mathrm{E}$ & -14.1 \\
\hline 29 & Octahcdron & E & -7.9 \\
\hline 34 & $\mathrm{O}+\mathrm{D}$ combination & $\mathrm{E}$ & -12.5 \\
\hline 37 & Dodecahedroid & $\mathrm{E}$ & -10.9 \\
\hline 42 & $O+D$ combination & $\mathrm{E}$ & -20.5 \\
\hline 43 & Dodecahedroid & & -5.4 \\
\hline 44 & Dodecahedroid & & -8.9 \\
\hline 45 & Twin of dodecahedroids & E & -18.3 \\
\hline 46 & Octahedron & $\mathrm{E}$ & -12.3 \\
\hline 47 & $\mathrm{O}+\mathrm{D}$ combination & & -12.4 \\
\hline 48 & Dodecahedroid & $\mathrm{E}$ & -11.6 \\
\hline 49 & Dodecahedroid & & -7.8 \\
\hline 52 & Dodccahcdroid & & -5.6 \\
\hline 54 & Twin of dodecahedroids & & -16.5 \\
\hline 55 & Dodecahedroid & $\mathrm{E}$ & -14.5 \\
\hline 60 & Dodecahedroid & $\mathrm{E}$ & -16.7 \\
\hline 65 & Octabedron & & -7.5 \\
\hline 66 & $\mathrm{O}+\mathrm{D}$ combination & $\mathrm{E}$ & -17.7 \\
\hline 67 & $\mathrm{O}+\mathrm{D}$ combination & & -5.8 \\
\hline 68 & Dodecahedroid & & -9.3 \\
\hline 71 & Dodecahedroid & & -18.7 \\
\hline 72 & $O+D$ combination & $\mathrm{E}$ & +0.4 \\
\hline 73 & Octahedron & & -10.0 \\
\hline 74 & $O+D$ combination & $\mathrm{E}$ & -14.9 \\
\hline 75 & Dodecahedroid & & -17.3 \\
\hline
\end{tabular}

Note: * U: ultramafic paragenesis, E: eclogitic paragenesis. analyzed. Seventeen diamond crystals $(89.5 \%)$ are of the eclogitic association, and only two crystals (10.5\%) contain minerals of the ultramafic suite (Table 4).

\section{Eclogitic-type inclusions}

The eclogite-suite inclusions (E-type inclusions) in the Los Coquitos diamond crystals are represented by garnet (pyrope-almandine), clinopyroxene (omphacite), ilmenite and probable coesite and wüstite.

Garnet of the pyrope-almandine series is abundant among the E-type inclusions. The ten grains have $m g$ [= $\mathrm{Mg} /(\mathrm{Mg}+\mathrm{Fe})]$ values of 0.49 to 0.59 (Table 5), which is slightly higher than garnet included in Quebrada Grande diamond crystals. The calcium index [ca\# = $\mathrm{Ca} /(\mathrm{Ca}+\mathrm{Mg}+\mathrm{Fe})]$ in these grains varies from 15 to 26 with an average of 19.5 . This is generally lower than in garnet inclusions in diamond crystals from the Quebrada Grande placers and sills. Figure 10 shows the $\mathrm{Mg}-\mathrm{Ca}-\mathrm{Fe}$ relationships of garnet inclusions from Los Coquitos, with the data for the Quebrada Grande placers and sills shown for comparison.

Trace-element patterns of six eclogitic garnet inclusions were determined by LAM-ICP-MS (Table 6). They show the high HREE and low LREE contents characteristic of most examples of eclogitic garnet (Fig. 11). Compared to similar inclusions from the Quebrada Grande placers and sills (Kaminsky et al. 2000), they show greater depletion in LREE (La, Ce, $\mathrm{Pr}$ ), lower $\mathrm{Sr}$ and $\mathrm{Nb}$ contents, and higher average contents of $\mathrm{Ga}, \mathrm{Zr}$ and $\mathrm{Ti}$ (Fig. 11).

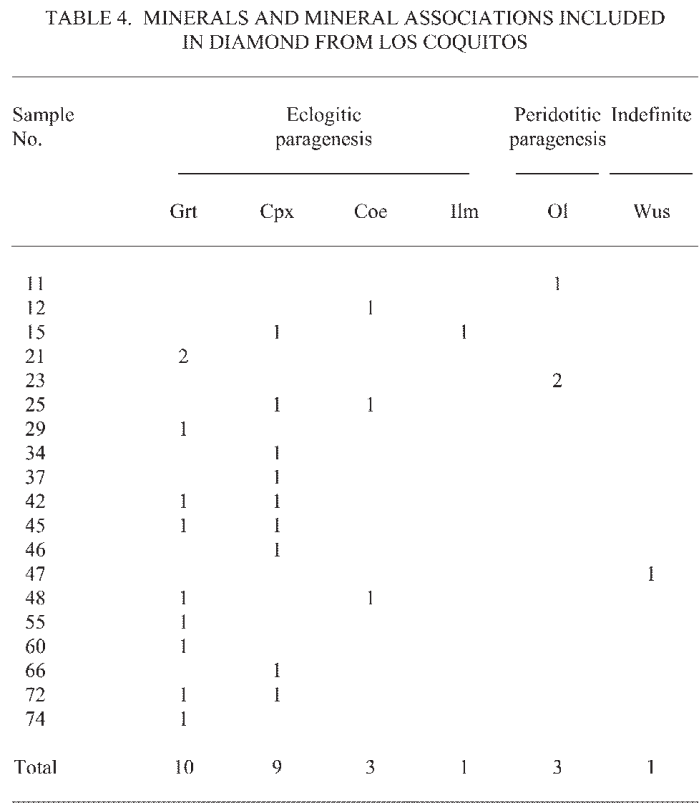

Symbols used: Grt: gamet, Cpx: clinopyroxene, Coe: coesite, Ilm: ilmenite, Ol: olivine, Wus: wüstite. 

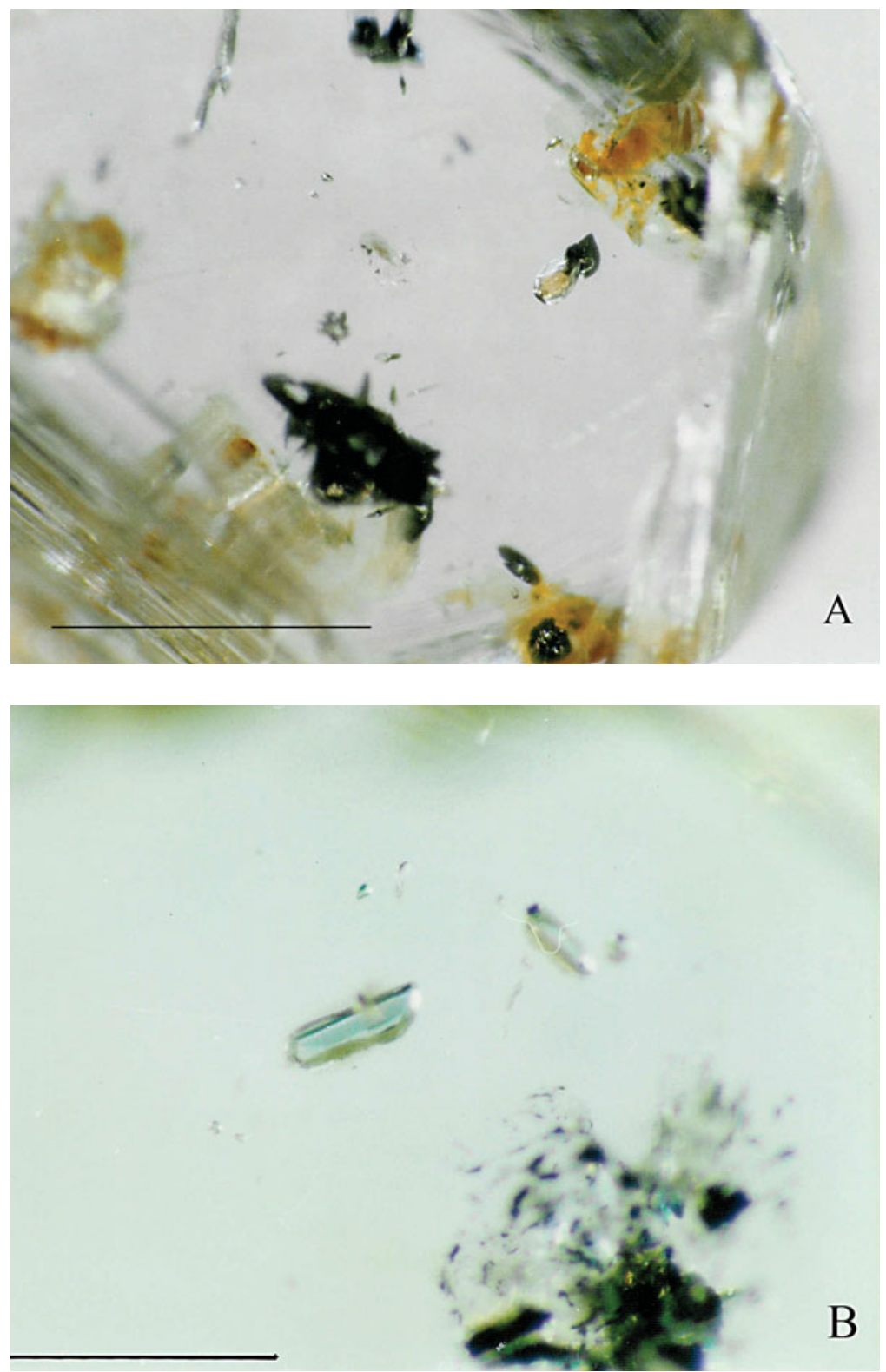

FIG. 9. Mineral inclusions in diamond crystals. A. Garnet and sulfide inclusions in diamond. B. Pyroxene and sulfide inclusions in diamond. Scale bar is $0.5 \mathrm{~mm}$.

Pyroxene (omphacite) is also abundant among the E-type mineral inclusions in the Los Coquitos diamond crystals. The chemical composition of nine pyroxene inclusions is presented in Table 7. The Na content varies from 3.2 to $6.6 \% \mathrm{Na}_{2} \mathrm{O}$, with an average of $5 \%$. The $\mathrm{Al}$ content varies from 8.6 to $12.6 \% \mathrm{Al}_{2} \mathrm{O}_{3}$ and shows a positive correlation with $\mathrm{Na}_{2} \mathrm{O}$. A characteristic feature of the pyroxene inclusions at Los Coquitos, which is similar to that seen in the Quebrada Grande sills and placers, is the high proportion of $\mathrm{K}\left(0.5\right.$ to $1.0 \% \mathrm{~K}_{2} \mathrm{O}$, average of $0.76 \%$ ). High $\mathrm{K}$ contents in pyroxene inclusions have been found in diamond crystals from the Argyle pipe and from pipes of the Arkhangelsk region (Sobolev et al. 1989). However, the K contents are 


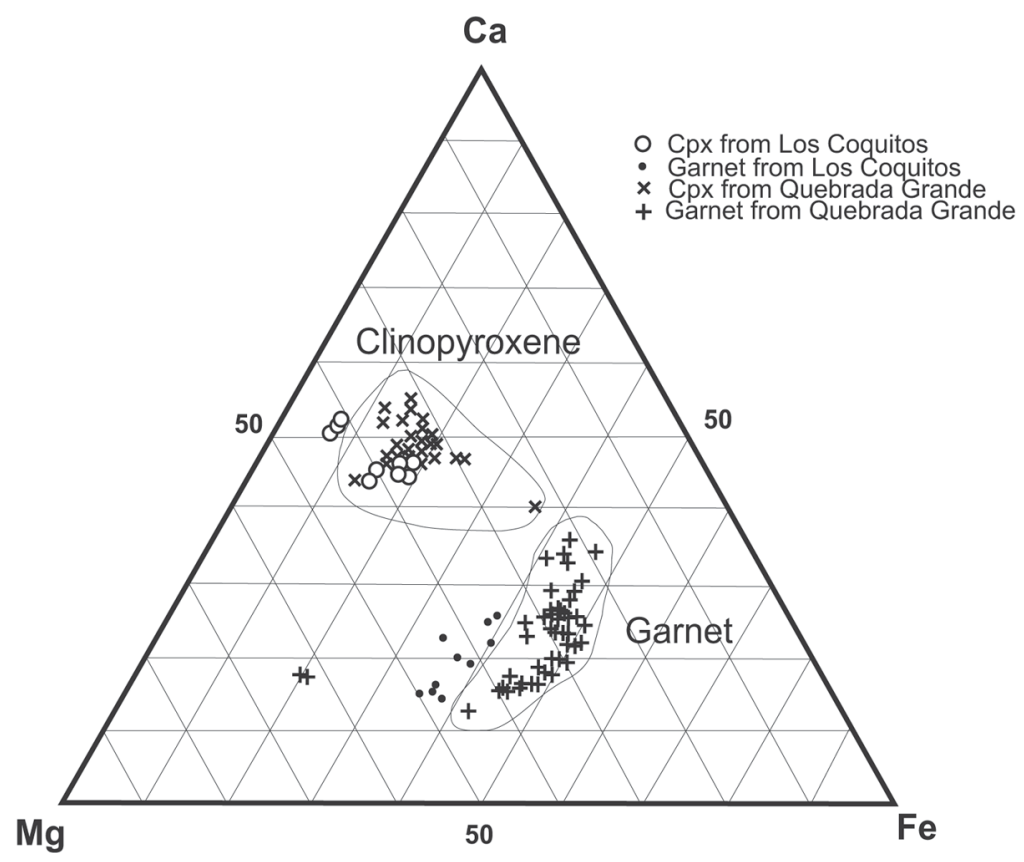

FIG. 10. Composition of garnet and clinopyroxene included in Los Coquitos diamond, in terms of $\mathrm{Mg}, \mathrm{Ca}$ and $\mathrm{Fe}$. The diagram also shows data for the same minerals from the Quebrada Grande sills and placers that are circled. Minerals from Los Coquitos have different ranges of composition.

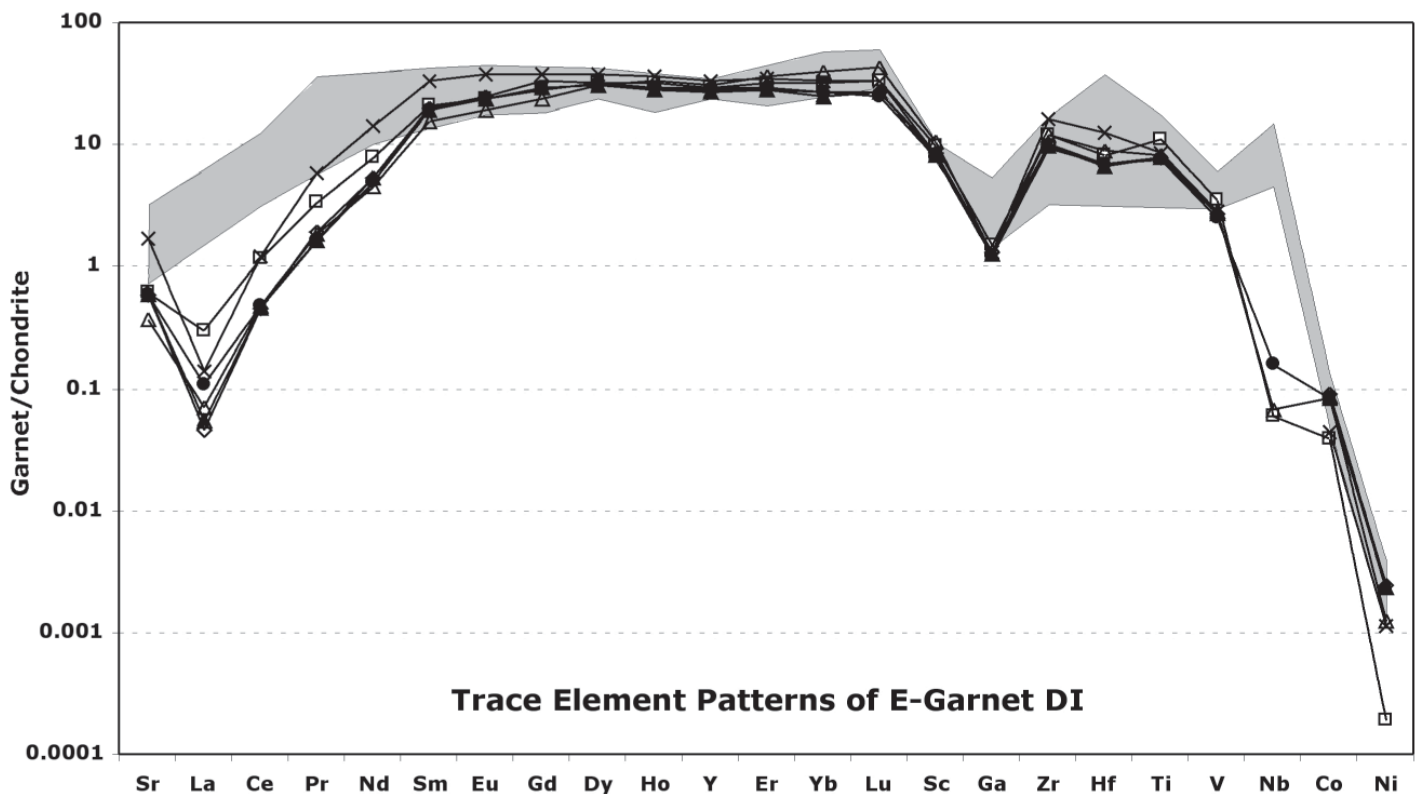

FIG. 11. Extended chondrite-normalized trace-element patterns for inclusions of garnet of eclogitic affinity in diamond crystals from Los Coquitos. Shaded field shows data for similar inclusions in diamond from the Quebrada Grande deposits (Kaminsky et al. 2000). 
TABLE 5. COMPOSITION OF GARNET INCLUDED IN DIAMOND FROM LOS COQUITOS

\begin{tabular}{|c|c|c|c|c|c|c|c|c|c|c|c|c|}
\hline Sample & $\mathrm{SiO}_{2}$ & $\mathrm{TiO}_{2}$ & $\mathrm{Al}_{2} \mathrm{O}_{3}$ & $\mathrm{Cr}_{2} \mathrm{O}_{3}$ & $\mathrm{FeO}$ & $\mathrm{MnO}$ & $\mathrm{MgO}$ & $\mathrm{CaO}$ & $\mathrm{Na}_{2} \mathrm{O}$ & $\mathrm{K}_{2} \mathrm{O}$ & Total & $m g$ \\
\hline $21(1)$ in wt. $\%$ & 39.94 & 0.59 & 22.35 & 0.04 & 18.28 & 0.42 & 9.73 & 9.54 & 0.21 & 0 & 101.10 & 0.49 \\
\hline $21(2)$ & 40.11 & 0.61 & 22.09 & 0.09 & 17.58 & 0.37 & 9.79 & 9.18 & 0.19 & n.d. & 100.01 & 0.50 \\
\hline 29 & 40.11 & 0.52 & 22.77 & 0.03 & 16.92 & 0.40 & 13.44 & 5.63 & 0.19 & 0.02 & 100.03 & 0.59 \\
\hline 42 & 40.02 & 0.60 & 22.50 & 0 & 18.49 & 0.40 & 10.26 & 7.88 & 0.17 & n.d. & 100.32 & 0.50 \\
\hline 45 & 40.45 & 0.50 & 22.53 & 0.02 & 16.98 & 0.37 & 13.32 & 5.92 & 0.24 & 0.01 & 100.34 & 0.58 \\
\hline 48 & 40.11 & 0.55 & 22.23 & 0.03 & 17.71 & 0.46 & 13.16 & 5.94 & 0.32 & 0 & 100.51 & 0.57 \\
\hline 55 & 39.66 & 0.53 & 22.46 & 0.03 & 17.85 & 0.35 & 12.92 & 5.97 & 0.30 & n.d. & 100.07 & 0.56 \\
\hline 60 & 39.75 & 0.59 & 22.29 & 0.15 & 17.93 & 0.40 & 11.66 & 7.26 & 0.24 & n.d. & 100.27 & 0.54 \\
\hline 72 & 39.66 & 0.61 & 21.84 & 0.10 & 18.81 & 0.43 & 11.51 & 7.39 & 0.17 & 0.03 & 100.55 & 0.52 \\
\hline 74 & 39.52 & 0.74 & 21.94 & 0.05 & 16.41 & 0.44 & 12.27 & 8.46 & 0.32 & 0.03 & 100.18 & 0.57 \\
\hline
\end{tabular}
INCLUDED IN DIAMOND FROMLOS COQUITOS

\begin{tabular}{|c|c|c|c|c|c|c|}
\hline Sample No. & 21 & 29 & 45 & 48 & 72 & 74 \\
\hline Sc ppm & 47.8 & 46.2 & 49.6 & 47.5 & 59.9 & 55.5 \\
\hline $\mathrm{Ti}$ & 3762 & 3248 & 3438 & 3393 & 3610 & 4702 \\
\hline $\mathrm{V}$ & 161 & 143 & 153 & 152 & 159 & 200 \\
\hline Co & 21.5 & 40.7 & 45.2 & 43.5 & 40.9 & 19.3 \\
\hline $\mathrm{Ni}$ & 12.3 & 24.3 & 26.3 & 25.6 & 13.6 & 2.12 \\
\hline Ga & 13.1 & 11.9 & 12.9 & 12.5 & 12.3 & 14.6 \\
\hline $\mathrm{Sr}$ & 13.1 & 4.60 & 4.65 & 4.58 & 2.83 & 4.69 \\
\hline Y & 51.5 & 42.7 & 45.0 & 42.6 & 47.6 & 46.4 \\
\hline $\mathrm{Zr}$ & 64.2 & 37.1 & 39.9 & 38.4 & 47.7 & 46.3 \\
\hline $\mathrm{Nb}$ & $<0.008$ & 0.04 & $<0.006$ & $<0.008$ & 0.02 & 0.01 \\
\hline $\mathrm{La}$ & 0.03 & 0.02 & 0.01 & 0.01 & 0.02 & 0.07 \\
\hline $\mathrm{Ce}$ & 0.72 & 0.28 & 0.27 & 0.27 & 0.29 & 0.70 \\
\hline $\operatorname{Pr}$ & 0.53 & 0.14 & 0.17 & 0.14 & 0.16 & 0.30 \\
\hline $\mathrm{Nd}$ & 6.45 & 2.23 & 2.41 & 2.38 & 2.00 & 3.52 \\
\hline $\mathrm{Sm}$ & 4.95 & 2.77 & 2.91 & 2.85 & 2.23 & 3.09 \\
\hline Eu & 2.15 & 1.35 & 1.39 & 1.35 & 1.06 & 1.30 \\
\hline $\mathrm{Gd}$ & 7.43 & 5.65 & 6.50 & 5.81 & 4.60 & 5.48 \\
\hline Dy & 8.95 & 7.49 & 7.80 & 7.52 & 7.50 & 7.81 \\
\hline Ho & 2.03 & 1.61 & 1.62 & 1.56 & 1.81 & 1.75 \\
\hline Er & 5.55 & 4.47 & 4.62 & 4.45 & 5.67 & 5.13 \\
\hline $\mathrm{Yb}$ & 5.36 & 4.31 & 4.35 & 4.05 & 6.25 & 5.11 \\
\hline $\mathrm{Lu}$ & 0.79 & 0.60 & 0.66 & 0.64 & 1.03 & 0.79 \\
\hline $\mathrm{Hf}^{\circ}$ & 1.29 & 0.73 & 0.72 & 0.69 & 0.91 & 0.86 \\
\hline $\mathrm{Ta}$ & 0,01 & 0.02 & $<0.004$ & $<0.005$ & $<0,003$ & $<0.005$ \\
\hline $\mathrm{Pb}$ & 0.94 & 0.92 & $<0.02$ & 0.04 & $<0.02$ & $<0.02$ \\
\hline Th & 0.01 & 0.02 & $<0.009$ & $<0.007$ & $<0.004$ & 0.01 \\
\hline U & 0.01 & 0.01 & $<0.003$ & $<0.006$ & $<0.003$ & 0.01 \\
\hline
\end{tabular}

much lower in pyroxene inclusions in diamond crystals from other regions.

The $\mathrm{Mg}-\mathrm{Ca}-\mathrm{Fe}$ characteristics of clinopyroxene inclusions from Los Coquitos are plotted in Figure 10. They show a wider compositional variation than those from the Quebrada Grande sills and placers and include three groups of omphacite: a high-magnesium group with $0.84<m g<0.85$, a relatively low-magnesium group with $0.68<m g<0.70$, and a transitional group of a wider range of composition, with $0.74<m g<$ 0.77 (Table 7).

Silica inclusions occur in three Los Coquitos diamond crystals as small colorless inclusions. In some cases, they are associated with orange garnet (\#48) and omphacite (\#25). These inclusions were analyzed; they are virtually pure $\mathrm{SiO}_{2}$. They are probably coesite.

A single inclusion of ilmenite was extracted from diamond crystal \#15, where it is in association (nontouching) with omphacite (Table 8). Like ilmenite inclusions from diamond crystals from the Quebrada Grande sills and placers, this one is characterized by a low $\mathrm{Mg}$ content $(0.10 \% \mathrm{MgO})$ and a higher than usual $\mathrm{Mn}$ content $(2.35 \% \mathrm{MnO})$. Low-Mg manganiferous ilmenite grains (with $<0.05-0.81 \% \mathrm{MgO}$ and $2-11 \% \mathrm{MnO}$ ) were also observed in superdeep diamond crystals from

TABLE 7. COMPOSITION OF PYROXENE INCLUDED IN DIAMOND FROM LOS COQUITOS

\begin{tabular}{lccrlllllllllll} 
Sample & $\mathrm{SiO}_{2}$ & $\mathrm{TiO}_{2}$ & $\mathrm{Al}_{2} \mathrm{O}_{3}$ & $\mathrm{Cr}_{2} \mathrm{O}_{3}$ & $\mathrm{FeO}$ & $\mathrm{MnO}$ & $\mathrm{MgO}$ & $\mathrm{CaO}$ & $\mathrm{Na}_{2} \mathrm{O}$ & $\mathrm{K}_{2} \mathrm{O}$ & Total & $m g$ \\
\hline \multirow{2}{*}{15 in wt.\% } & 55.09 & 0.58 & 9.67 & 0.06 & 3.38 & 0 & 10.63 & 16.88 & 3.17 & 1.00 & 100.46 & 0.85 \\
25 & 54.87 & 0.55 & 9.82 & 0.03 & 3.45 & 0.06 & 10.50 & 16.90 & 3.47 & 1.01 & 100.66 & 0.84 \\
34 & 54.77 & 0.70 & 12.55 & 0.02 & 6.02 & 0.06 & 7.29 & 12.05 & 6.59 & 0.50 & 100.55 & 0.68 \\
37 & 55.38 & 0.48 & 12.45 & 0.03 & 5.68 & 0.08 & 7.38 & 11.83 & 6.59 & 0.53 & 100.43 & 0.70 \\
42 & 54.19 & 0.76 & 8.59 & 0 & 7.31 & 0.06 & 8.81 & 14.53 & 4.43 & 0.87 & 99.55 & 0.68 \\
45 & 54.92 & 0.50 & 8.76 & 0 & 7.43 & 0.09 & 8.98 & 14.78 & 4.33 & 0.69 & 100.48 & 0.68 \\
46 & 54.95 & 0.55 & 10.03 & 0.08 & 3.52 & 0 & 10.60 & 15.80 & 3.40 & 0.84 & 99.77 & 0.84 \\
66 & 55.19 & 0.76 & 11.50 & 0.04 & 5.19 & 0.09 & 8.19 & 12.92 & 5.70 & 0.66 & 100.24 & 0.74 \\
72 & 56.28 & 0.37 & 9.12 & 0.06 & 5.35 & 0.10 & 10.07 & 13.72 & 4.78 & 0.57 & 100.42 & 0.77
\end{tabular}


Juina, Brazil (Kaminsky et al. 2001a); some of them were in association with ferroan periclase, majorite and perovskite. However, in this case, the low-Mg manganiferous ilmenite is associated with omphacite and belongs to the eclogitic association.

Using geothermobarometers for the eclogitic association of mineral inclusions (Simakov 2003), the equilibrium conditions of temperature and pressure for eight inclusions of pyroxene in Los Coquitos diamond were estimated (the inclusion from \#72 seems to have too low a CaTs component) based on both single-mineral and association methods (Table 9). The equilibrium temperature and pressure estimates for the Los Coquitos diamond crystals cover a wide range: $1060-1767^{\circ} \mathrm{C}$ and 4.10-8.34 GPa. These figures, in general, overlap the P-T estimates for Quebrada Grande diamond crystals (974-1450 ${ }^{\circ} \mathrm{C}$ and 5.24-6.15 GPa; Kaminsky et al. 2000), but extend to higher P-T conditions. These maximal temperatures seem to be higher than for most of inclusions in diamond worldwide. To check the results, we calculated equilibrium temperatures for two garnet-pyroxene pairs (samples \#42 and \#45) using the Ellis \& Green (1979) geothermometer and the

\begin{tabular}{|c|c|c|c|c|c|c|c|c|}
\hline Sample & $\mathrm{TiO}_{2}$ & $\mathrm{Al}_{2} \mathrm{O}_{3}$ & $\mathrm{Cr}_{2} \mathrm{O}_{3}$ & $\mathrm{FeO}$ & $\mathrm{MnO}$ & MgO & Total & $m g$ \\
\hline \multicolumn{9}{|c|}{ IImenite } \\
\hline 15 in wt. $\%$ & 54.94 & 0.05 & 0 & 40.74 & 2.35 & 0.10 & 98.18 & 0.004 \\
\hline \multicolumn{9}{|c|}{ Wiistite } \\
\hline 47 & 0.03 & 0.12 & 0.02 & 97.00 & 0.30 & 0.09 & 97.56 & 0.002 \\
\hline
\end{tabular}

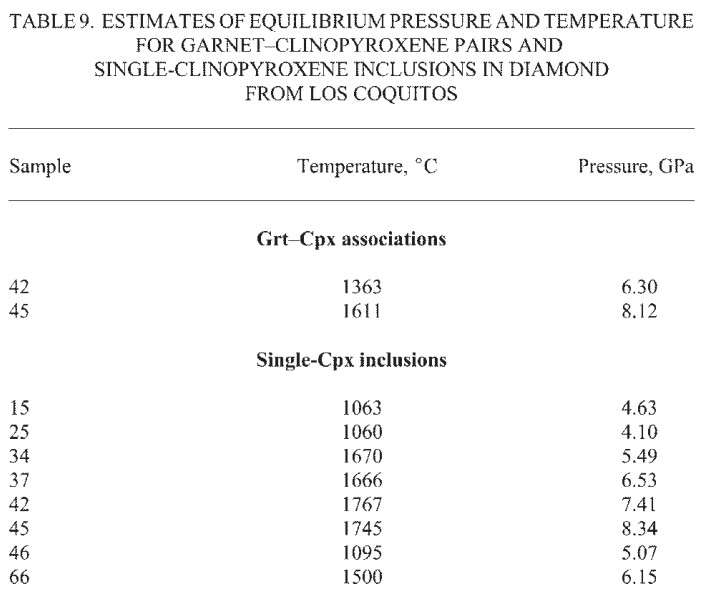

GEMOC's PT-Hotstuff98 program. For sample \#42, the equilibrium temperature was $1351^{\circ} \mathrm{C}$ at $6.0 \mathrm{GPa}$ versus $1363^{\circ} \mathrm{C}$ and $6.30 \mathrm{GPa}$ derived from the Simakov (2003) method; for sample \#45, the equilibrium temperature was $1605^{\circ} \mathrm{C}$ at $8.0 \mathrm{GPa}$ versus $1611^{\circ} \mathrm{C}$ and $8.12 \mathrm{GPa}$ derived from the Simakov (2003) method (Table 9). These results confirm other data obtained with the use of Simakov's method and support the conclusion that some of the Los Coquitos diamond crystals came from a different section of lithospheric mantle.

\section{Ultramafic-type inclusions}

Ultramafic-type inclusions are represented only by olivine. Three inclusions were analyzed, two from diamond \#23 and one from diamond \#11. Olivine compositions are presented in Table 10. All three olivine inclusions have similar forsterite contents $(m g=0.93)$ and contain average concentrations of $\mathrm{Ni}(0.25-0.33$ wt.\% $\mathrm{NiO})$ and $\mathrm{Cr}\left(0.05-0.11\right.$ wt. $\left.\% \mathrm{Cr}_{2} \mathrm{O}_{3}\right)$. Olivine inclusions from Los Coquitos diamond crystals are characterized by a slightly lower forsterite component than in the Quebrada Grande placers and sills (0.93 $<m g<0.95$ ). However, they are similar to olivine inclusions occurring in diamond crystals from other regions.

The paragenetic type of one inclusion in a Los Coquitos diamond remains unidentified. A single inclusion of wüstite was recorded in sample \#47, in the central part of a combination-type, octahedral + dodecahedral crystal. There are no cracks in the crystal, indicating that the wüstite is not epigenetic. The wüstite \#47 has $97 \% \mathrm{FeO}$ with only $0.09 \% \mathrm{MgO}$ and $m g=0.002$ (Table 8). This is very different from lower-mantle ferroan periclase-wüstite solid solution, which has a wide variation in $m g$ (from 0.38 to 0.85 ; Harte et al. 1999, Kaminsky et al. 2001a). The electron-microprobe analysis of wüstite gave low analytical totals, which may indicate the existence of other, non-determined elements in the structure.

\section{DISCUSSION}

All diamond crystals from the Los Coquitos placer are characterized by a lack of any significant marks of intense mechanical abrasion. This finding suggests that the Los Coquitos diamond, like diamond from

TABLE 10. COMPOSITION OF OLIVINE INCLUDED IN DIAMOND FROM LOS COQUITOS

\begin{tabular}{llllllllllll} 
Sample & $\mathrm{SiO}_{2}$ & $\mathrm{Al}_{2} \mathrm{O}_{3}$ & $\mathrm{Cr}_{2} \mathrm{O}_{3}$ & $\mathrm{FeO}$ & $\mathrm{NiO}$ & $\mathrm{MnO}$ & $\mathrm{MgO}$ & $\mathrm{CaO}$ & Total & $m g$ \\
\hline 11 in wt.\% & 41.07 & 0.01 & 0.07 & 6.47 & 0.25 & 0.07 & 50.09 & 0.03 & 98.06 & 0.94 \\
$23(1)$ & 41.36 & 0 & 0.05 & 6.70 & 0.29 & 0.09 & 50.66 & 0 & 99.15 & 0.93 \\
$23(2)$ & 40.70 & 0 & 0.11 & 7.15 & 0.33 & 0.09 & 49.88 & 0 & 98.26 & 0.93
\end{tabular}


the Quebrada Grande placers, has not been reworked from ancient sediments and transported long distances within alluvial systems, as had been suggested for all Venezuelan diamond deposits by Reid (1972), but are of local origin. Kaminsky et al. (2000) showed that the Quebrada Grande placer diamond crystals are also of local origin; in that case, the source kimberlites are immediately adjacent to the alluvial deposits. The Quebrada Grande placers extend from the kimberlite sill outcrops around the towns of Salvación and Milagro for $30 \mathrm{~km}$ downstream to the junction of the Quebrada Grande with the north-flowing Guaniamo River. The placers have been worked by artisanal miners right up to this point. The $20 \mathrm{~km}$ reach of the Guaniamo River from the junction with the Quebrada Grande is primarily erosional, with numerous rapids, and it is not until Los Coquitos where the Guaniamo turns sharply to the east, that gravel bars have accumulated. Given the relatively short distance of transport from the Quebrada Grande sills to Los Coquitos (50 to $60 \mathrm{~km}$ ) and the numerous similarities between diamond crystals from the two areas, it is reasonable to suggest that some of the Los Coquitos diamond crystals were derived by downstream transport of Quebrada Grande diamond crystals. However, there are some very significant differences between diamond crystals from the two areas, which confirm the presence of other, undiscovered primary sources within the Guaniamo River valley. Similarities and differences between diamond crystals from the two areas are summarized in Table 11.

The principal physical similarities between Los Coquitos and Quebrada Grande diamond crystals include the predominance of dodecahedroids with lamellarstepped surfaces, similar proportions of dodecahedral twins and aggregates, a presence of various post-growth surface features and green pigmentation spots, mostly colorless diamond crystals, predominantly blue luminescence, and similar infrared spectral characteristics, with comparable average concentrations of B-nitrogen impurity centers, platelets and hydrogen. In addition, diamond crystals from the two areas are dominated by isotopically light carbon, with most diamond crystals having a $\delta^{13} \mathrm{C}$ below $-10 \%$. Also, mineral inclusions in diamond are dominated by the eclogitic paragenesis, of which the mineral types and chemical compositions are comparable between the two regions.

For the diamond crystals with crystalline mineral inclusions, a correlation was observed between the isotopic composition and the paragenetic affinity of the mineral inclusion. The rare crystals with mineral inclusions of ultramafic paragenesis are isotopically heavy $\left(3.3<\delta^{13} \mathrm{C}<6.1 \%\right.$ ). The majority of diamond crystals with inclusions of eclogite-suite minerals are isotopically light. Only two exceptions are isotopically heavy, and one of these has a positive $\delta^{13} \mathrm{C}$ value.

On the other hand, Los Coquitos diamond crystals differ from Guaniamo crystals in the following ways:
1) significantly higher proportions of octahedra, combination-type and uncertain-type crystals, and a more restricted spectrum of dodecahedral and octahedral types,

2) the presence of yellow crystals, a lower proportion of smoky-brown diamond crystals and higher proportions of green crystals and crystals with pigmentation spots,

3) a higher proportion of transparent crystals and a lower proportion of non-transparent crystals,

4) a higher proportion of diamond crystals with blue photoluminescence and a lower proportion of crystals emitting photoluminescence of other colors; no stones with pink or block-type luminescence,

5) a higher relative abundance of A-type nitrogen centers relative to $\mathrm{B}$ and $\mathrm{P}$ centers,

6) a higher proportion of diamond crystals with isotopically heavy carbon isotope compositions, and

7) some distinct compositional features of mineral inclusions in diamond crystals, such as a lower calcium in garnet, wider compositional variations in pyroxene, lower forsterite component in olivine, above-average contents of $\mathrm{K}$ in pyroxene and $\mathrm{Mn}$ in ilmenite, and some differences in the trace-element patterns of the eclogitic garnet inclusions.

Some of these differences seem insignificant, but taken together, they demonstrate that the Los Coquitos and the Quebrada Grande diamond crystals represent two different populations.

The differences in the physical characteristics of the Los Coquitos diamond crystals, combined with the differences in carbon isotopic compositions, nitrogen impurity types and abundances, and mineral compositions, indicate that a separate mantle-source supplied at least some of the Los Coquitos diamond crystals. The general similarities between the two areas suggest that the source region in the mantle for the Los Coquitos diamond crystals is generally similar to that for the kimberlites in Quebrada Grande. However, the differences are sufficient to conclude that the locations of the two sources are different, and that each sampled a different region of the lithospheric mantle. The Los Coquitos placer most likely contains a mixture of diamond crystals from two different primary sources, one in the Quebrada Grande valley and the other as yet undiscovered.

The Los Coquitos region is located at a structural transfer zone at the western side of a major northwesttrending Proterozoic rift structure, along which flows the Guaniamo River. The presence of highly diamondiferous and extensive kimberlite sills in Guaniamo adjacent to the Quebrada Grande, combined with a highly favorable regional structural setting, together make for a very prospective environment for discovery of new kimberlites.

The existence of two populations of diamond, each with its own primary source, suggests that other 
TABLE 11. SUMMARY OF SIMILARITIES AND DIFFERENCES IN DIAMOND BETWEEN THE LOS COQUITOS (LC) AND QUEBRADA GRANDE (QG) SUITES

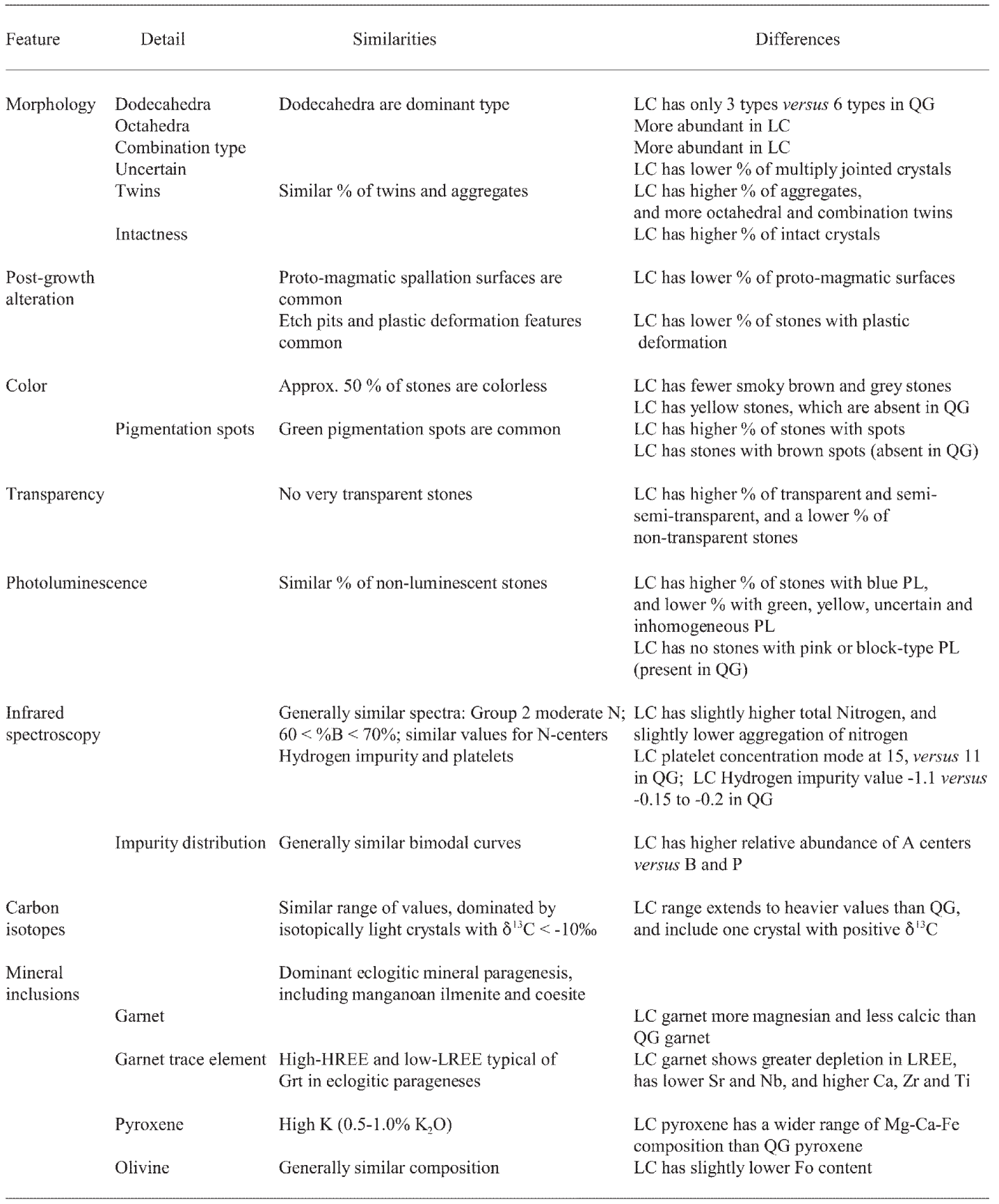

placer diamond localities in Venezuela probably have their own local (probably kimberlitic) sources. In this case, the diamondiferous kimberlites discovered in the Guaniamo area (Channer et al. 2001) may be the first in a new Venezuelan diamondiferous kimberlite province. 
The estimates of the equilibrium temperature and pressure for Los Coquitos diamond crystals, covering a wider range than Quebrada Grande crystals (1060$1767^{\circ} \mathrm{C}$ and $4.10-8.34 \mathrm{GPa}$ versus $974-1450^{\circ} \mathrm{C}$ and 5.24-6.15 GPa), support the conclusion that some of the Los Coquitos diamond crystals came from a different section of lithospheric mantle.

Ferroan periclase, typical of the superdeep paragenesis, is included in diamond crystals with a "juvenile" carbon isotopic composition, with $\delta^{13} \mathrm{C}$ from -3 to $-6 \%$ PDB (e.g., Harte et al. 1999, Kaminsky et al. 2001b). In contrast to periclase-including diamond, crystal \#47 has a "light" carbon isotopic composition, with $\delta^{13} \mathrm{C}=-12.4 \%$ o PDB (see Table 3). Judging by this criterion, it could be suggestive of E-type. In this case the wüstite might be a remnant of subducted crustal material, containing Fe-ores, banded iron formation, etc. However, another hypothesis can be considered as an alternative. According to experiments by Badro et al. (2003), ferroan periclase in the lowermost mantle $(1700-2900 \mathrm{~km})$ must be enriched in Fe because of the transition from high-spin to low-spin state of Fe at $70 \mathrm{GPa}$. There are observed indications of increasing content of iron in lower mantle mineral phases toward the core-mantle boundary, e.g., ilmenite, chromian spinel and "olivine" in lower mantle associations are characterized by a higher iron index than the same phase in upper mantle (e.g., Harte et al. 1999, Kaminsky et al. 2001b). Considering this hypothesis, the wüstite in crystal \#47 may well belong to the lowermost mantle. This hypothesis needs further study.

On the basis of the carbon isotopic data, a subduction-related origin for the eclogitic-suite diamond crystals in the Quebrada Grande was previously suggested (Sobolev et al. 1998, Kaminsky et al. 2000). Strong support for this idea was provided by Schulze et al. (2003a, b), who found that the $\delta^{18} \mathrm{O}$ of coesite preserved in diamond from Guaniamo ranges from +10.2 to $+16.9 \%$; values as high as these commonly are explained by the subduction of oceanic metabasalts, with subsequent incorporation of this eclogitized material into the subcontinental lithospheric mantle. The Los Coquitos diamond crystals show a similarly strong eclogitic signature, including the presence of a diamond crystal with a positive $\delta^{13} \mathrm{C}$ value. Diamond crystals with such heavy carbon isotopic characteristics are the dominant population in placers from southeastern Australia (Sobolev et al. 1979), which are considered a classic example of "subducted diamond" (Davies et al. 2002, 2003, and references therein). This may imply that the mantle beneath a large region of western Venezuela may contain eclogite as a source material.

\section{ACKNOWLEDGEMENTS}

We thank Guaniamo Mining Co. and Robert E. Cooper for financing this project and granting us permission to publish these materials, Oliver Gaul and Suzie Elhlou for carrying out the trace-element analyses. We are also in gratitude to Sergei Simakov for helping us to calculate P-T estimates using his original technique, Ariane Nelson and particularly Dr. B. Kjarsgaard for thoughtful and careful editing, which improved the manuscript. This is publication no. 410 from the ARC National Key Centre for the Geochemical Evolution and Metallogeny of Continents (GEMOC).

\section{REFERENCES}

Badro, J., Fiquet, G., Guyot, F., RuefF, J.-P., Struzhrin, V.V., VANKó, G. \& Monaco, G. (2003): Iron partitioning in Earth's mantle: toward a deep lower mantle discontinuity. Science 300, 789-791.

BARTOSHINSKy, Z.V. (1962): Crystallography of Yakutian Diamond Crystals. Ph.D. thesis, L'vov University, L'vov, Russia (in Russ.).

Boyd, S.R., KIFLAWI, I. \& WoOdS, G.S. (1994): The relationship between infrared absorption and the A defect concentration in diamond. Phil. Mag. B69, 1149-1153.

Boyd, S.R., KifLawI, I. \& Woods, G.S. (1995): Infrared absorption by the B nitrogen aggregate in diamond. Phil. Mag. B72, 351-361.

Channer, D.M.DeR., Egorov, A. \& Kaminsky, F. (2001): Geology and structure of the Guaniamo diamondiferous kimberlite sheets, south-west Venezuela. Revista Brasileira de Geociências 31, 615-630.

DaVIES, R.M., GrifFin, W.L., O'ReILly, S.Y. \& ANDREW, A.S. (2003): Unusual mineral inclusions and carbon isotopes of alluvial diamond crystals from Bingara, eastern Australia. Lithos 69, 51-66.

Davies, R.M., Griffin, W.L., O'Reilly, S.Y. \& Doyle, B.J. (2004): Mineral inclusions and geochemical characteristics of microdiamonds from the DO27, A154, A21, A418, DO18, DD17 and Ranch Lake kimberlites at Lac de Gras, Slave Craton, Canada. Lithos 77, 39-55.

Davies, R.M., O’Reilly, S.Y. \& GRIFFIN, W.L. (2002): Multiple origins of alluvial diamonds from New South Wales, Australia. Econ. Geol. 97, 109-123.

Ellis, D.J. \& GreEN, D.H. (1979): An experimental study of the effect of $\mathrm{Ca}$ upon garnet-clinopyroxene $\mathrm{Fe}-\mathrm{Mg}$ exchange equilibria. Contrib. Mineral. Petrol. 71, 13-22.

Galimov, E.M., KaminskiY, F.V. \& Ivanovskaya, I.N. (1978): Carbon isotope composition of diamonds from the Urals, Timan, Sayan, the Ukraine, and elsewhere. Geochem. Int. 15(2), 11-18.

GURNEY, J.J. \& HARRIS, R.R.S. (1982): Silicate and oxide inclusions in diamond crystals from Orapa mine, Botswana. Terra Cognita 2(3), 102 (abstr.).

Gurney, J.J., Harris, J.W., Rickard, R.S. \& MoORe, R.O. (1985): Inclusions in Premier mine diamond crystals. Trans. Geol. Soc. S. Afr. 88, 301-310. 
HARTE, B. \& HARRIS, J.W. (1994): Lower mantle mineral association preserved in diamond crystals. Mineral. Mag. 58A, 384-385.

Harte, B., Harris, J.W., Hutchison, M.T., Watt, G.R. \& WILDING, M.C. (1999): Lower mantle mineral associations in diamond crystals from Sao Luiz, Brazil. In Mantle Petrology: Field Observations and High Pressure Experimentation: a Tribute to Francis R. (Joe) Boyd (Yingwei Fei, C.M. Bertka \& B.O. Mysen, eds.). Geochem. Soc., Spec. Publ. 6, 125-153.

KAMINSKY, F.V. \& KHACHATRYAN, G.K. (2001): Characteristics of nitrogen and other impurity in diamond, as revealed by infrared absorption data. Can. Mineral. 39, 1735-1745.

KAMINSKY, F.V. \& KhachatRYAN, G.K. (2004): The relationship between the distribution of nitrogen impurity centres in diamond crystals and their internal structure and mechanism of growth. Lithos 77, 255-271.

Kaminsky, F.V., Sablukov, S.M., Sablukova, L.I. \& ChanNER, D.M.DeR. (2004): Neoproterozoic "anomalous" kimberlites of Guaniamo, Venezuela: mica kimberlites of "isotopic transitional" type. Lithos 76, 565-590.

Kaminsky, F.V., ZaKharchenko, O.D., DaVIes, R., GRIFFIN, W., Khachatryan-Blinova, G. \& ShiRYaev, A.A. (2001a): Superdeep diamond crystals from the Juina area, Mato Grosso State, Brazil. Contrib. Mineral. Petrol. 140, 734753.

Kaminsky, F.V., ZaKharchenKo, O.D., Griffin, W.L., ChanNeR, D.M.DeR. \& Khachatryan-Blinova, G.K. (2000): Diamond from the Guaniamo area, Venezuela. Can. Mineral. 38, 1347-1370.

KAMINSKY, F.V., ZAKHARCHENKO, O.D., KHACHATRYAN, G.K. \& Shiryaev, A.A. (2001b): Diamonds from the Coromandel area, Minas Gerais, Brazil. Revista Brasileira de Geociências 31, 583-596.

KHACHATRYAN, G.K. \& KAMINSKY, F.V. (2003): "Equilibrium" and "non-equilibrium" diamond crystals from deposits in the East European Platform, as revealed by infrared absorption data. Can. Mineral. 41, 171-184.

Kukharenko, A.A. (1955): Diamond Crystals of the Urals. Geoltekhizdat Publishing House, Moscow, Russia (in Russ.).

Mendelssohn, M.J. \& Milledge, H.J. (1995): Geologically significant information from routine analysis of the midinfrared spectra of diamond crystals. Int. Geol. Rev. 37, 95-110.

Meyer, H.O.A. (1982): Mineral inclusions in natural diamond. In Proc. Int. Gemological Symp. (Santa Monica), 445-465.

Orlov, Yu.L. (1984): Mineralogy of Diamond Crystals. Nauka Publishing House, Moscow, Russia (in Russ.). English translation published in 1987 by John Wiley and Sons, New York, N.Y.

Otter, M.L., GuRney, J.J. \& McCAndLess, T.E. (1989): The carbon isotope composition of Sloan diamond crystals. In
Workshop on Diamond Crystals. $28^{\text {th }}$ Int. Geol. Congress, Extended Abstr., 76-79.

REID, A.R. (1972): Stratigraphy of the type area of the Roraima Group, Venezuela. In Memoria de la IX Conferenca InterGuayanas. Boletin de Geologia, Publ. Esp. 6.

Robinson, D.R., Scott, J.A., VAn Niekerk, A. \& AnderSON, V.J. (1989): The sequence of events reflected in the diamond crystals of some Southern African kimberlites. In Kimberlites and Related Rocks. 2. Their Mantle/Crust Setting (J. Ross et al., eds.). Geol. Soc. Aust., Spec. Publ. 14, 990-1000.

Schulze, D.J., Harte, B., Valley, J.W., Brenan, J.M. \& Channer, D.M.DeR. (2003a): Extreme crustal oxygen isotope signatures preserved in coesite in diamond. Nature 423, 68-70

Schulze, D.J., Valley, J.W., Spicuzza, M.J \& Channer, D.M.DER. (2003b): Oxygen isotope composition of eclogitic and peridotitic garnet xenocrysts from the La Ceniza kimberlite, Guaniamo, Venezuela. Int. Geol. Rev. 45, 968-975.

Simakov, S.K. (2003): Physico-Chemical Aspects of Diamond-Bearing Eclogites Formation in the Upper Mantle and Earth Crust Rocks. Far East Branch, Russian Academy of Sciences, Magadan, Russia.

Sobolev, N.V., Galimov, E.M., Ivanovskaya, I.N. \& YefiMOVA, E.S. (1979): Isotopic composition of carbon of diamonds containing crystalline inclusions. Dokl. Akad. Nauk SSSR 249(5), 1217-1220 (in Russ.).

Sobolev, N.V., Galimov, E.M., Smith, C.B., Yefimova, E.S., Maltsev, K.A., Hall, E.E. \& Usova, L.V. (1989): Morphology, inclusions and carbon isotopic composition of diamond crystals from the King George alluvial deposit and the Argyle lamproitic pipe, Western Australia. Geologiya i Geofizika, No. 12, 3-18.

Sobolev, N.V., Yefimova, E.S., Channer, D.M.DeR., ANDERSON, P.F.N. \& BARRON, K.M. (1998): Unusual upper mantle beneath Guaniamo, Guyana shield, Venezuela: evidence from diamond inclusions. Geology 26, 971-974.

TAYLOR, W.R. \& MiLLEDGE, H.J. (1995): Nitrogen aggregation character, thermal history and stable isotope composition of some xenolith-derived diamond crystals from Roberts Victor and Finch. In Sixth Int. Kimberlite Conf., Extended Abstr. (Novosibirsk), 620-622.

Tolansky, S. (1955): The Microstructures of Diamond Surfaces. N.A.G. Press, London, U.K.

Zakharchenko, O.D., Kharkiv, A.D., Botova, M.M., MAKHIN, A.I. \& PAVLENKO, T.A. (1991): Inclusions of deep seated minerals in diamond crystals from kimberlite rocks of the north of the East European Platform. Mineral. Zh. 13(1), 42-52 (in Russ.).

Received February 7, 2005, revised manuscript accepted January 4, 2006 